\title{
Conservation status and spatial patterns of AGRRA vitality indices in Southwestern Atlantic Reefs
}

\author{
Ruy K.P. Kikuchi ${ }^{1}$, Zelinda M.A.N. Leão ${ }^{1}$ \& Marília D.M. Oliveira ${ }^{1}$ \\ 1. Universidade Federal da Bahia, CPGG/IGEO, Rua Caetano Moura 123, Federação, Salvador, 40210-340, Bahia, \\ Brasil; kikuchi@ufba.br; zelinda@ufba.br; mariliad@ufba.br
}

Received 30-VIII-2009. Corrected 01-X-2009. Accepted 07-XII-2009.

\begin{abstract}
Coral reefs along the Eastern Brazilian coast extend for a distance of $800 \mathrm{~km}$ from $12^{\circ}$ to $18^{\circ} \mathrm{S}$. They are the largest and the richest reefs of Brazil coasts, and represent the Southernmost coral reefs of the Southwestern Atlantic Ocean. Few reef surveys were performed in the 90's in reef areas of Bahia State, particularly in the Abrolhos reef complex, in the Southernmost side of the state. A monitoring program applying the Atlantic and Gulf Rapid Reef Assessment (AGRRA) protocol was initiated in 2000, in the Abrolhos National Marine Park, after the creation of the South Tropical America (STA) Regional Node of the Global Coral Reef Monitoring Network (GCRMN) by the end of 1999. From that time up to 2005, nine reef surveys were conducted along the coast of the State of Bahia, including 26 reefs, with 95 benthic sites, 280 benthic transects, 2025 quadrats and 3537 stony corals. Eighteen of the 26 investigated reefs were assessed once and eight reefs of Abrolhos were surveyed twice to four times. The MDS ordination, analysis of similarity (ANOSIM, one way and two-way nested layouts) and similarity percentages (SIMPER) tests were applied to investigate the spatial and temporal patterns of reef vitality. Four indicators of the coral vitality: live coral cover, the density of the larger corals (colonies $>20 \mathrm{~cm}$ per reef site) and of the coral recruits (colonies $<2 \mathrm{~cm}$ per square meter), and the percentage of macroalgae indicate that the nearshore reefs, which are located less than $5 \mathrm{~km}$ from the coast, are in poorer condition than the reefs located more than $5 \mathrm{~km}$ off the coast. A higher density of coral colonies, lower macroalgal index, higher relative percent of turf algae and higher density of coral recruits in offshore reefs compared to the nearshore reefs are the conditions that contribute more than $80 \%$ to the dissimilarity between them. The offshore reefs are in better vital condition than the nearhore reefs and have a set of vitality indices more closely related to the Northwestern Atlantic reefs than the nearshore reef. These have been most severely impacted by the effects of direct human activities such as euthrophic waters associated with sewage pollution, higher sedimentation rates and water turbidity, inadequate use of the reefs and over exploitation of their resources. The implementation of a more effective coral reef monitoring program in Bahia is mandatory, in order to improve the strategies for protection and management efforts of the reefs. Rev. Biol. Trop. 58 (Suppl. 1): 1-31. Epub 2010 May 01.
\end{abstract}

Key words: Eastern Brazil, coral reefs, AGRRA protocol, reef monitoring.

The coral reefs of Eastern Brazil are spread along $800 \mathrm{~km}$ of the coastline of Bahia state (between $12^{\circ}, 18^{\circ} \mathrm{S}$ ), and are the Southernmost reefs of the Atlantic Ocean.

The first vital condition evaluation of the coral reefs located along the Brazilian Eastern coast were performed during the years of 1996 to 1998. In this opportunity, the major reef building coral species present on the exposed top of fossil reefs (2.5 to $3.5 \mathrm{ky}$ old) located adjacent to the coastline, were compared with the living surface of submerged shallow (4-6m) reefs. These studies showed that, the $5 \mathrm{~m}$ decrease in sea level that occurred after 5 ky B.P., exposed the nearshore reefs to solar radiation and higher influx of land sediment, 
and caused a catastrophic coral cover decline, from a maximum of $14.5 \%$ in fossil reefs to a maximum of $3.5 \%$ in live reefs (Leão et al. 1997, Kikuchi \& Leão 1998, Kikuchi 2000).

Studies carried out in the last ten years, revealed that the reefs along the Eastern Brazilian coast are experiencing increasing degradation due to a variety of natural processes and anthropogenic perturbations, such as euthrophic waters, increasing sedimentation, marine pollution, and inadequate use of reef resources (Leão \& Kikuchi 2005, Gasparini et al. 2005, Leão et al. 2006).

In the North coast of Bahia State, the concentration of nitrate, nitrite, ammonia, phosphate and silicate from groundwater of a highly urbanized area surrounding nearshore reefs, is higher than the one from a low human occupation area, suggesting that the euthrophication of coastal waters, due to contamination by domestic sewage, is affecting the community structure of these nearshore reefs. Furthermore, these areas are also characterized by an increasing growth of turf and macroalgae, causing a reduction in the living coral coverage and favoring the activity of planktivorous reef macroborers (Costa Jr. 1998, Costa Jr. et al. 2000). Measures of the bioerosion rate in corals from these nearshore reefs revealed that boring sponges and bivalves represented more than $50 \%$ of the macroborers infestation (Santa-Izabel et al. 2000, Santa-Izabel 2001, Reis 2001, Reis \& Leão 2003).

Prior quantitative benthic surveys conducted in the reefs of the Abrolhos area (where species diversity of the shallow benthic fauna and flora were measured), in the Southern part of the state, pointed out some signals of reef degradation, mainly due to contamination of coastal waters (Pitombo et al. 1988, Coutinho et al. 1993, Figueiredo 1997, Villaça \& Pitombo 1997).

After the creation of the Southern Tropical America Regional Node (STA) of the Global Coral Reef Monitoring Network by the end of 1999, patch reefs located near Salvador City, the Caramuanas Reefs, facing the ocean side of Itaparica Island at the entrance of Todos os Santos Bay, were quantitatively assessed for the first time, as part of a training test for assessing the coral reefs of Bahia, applying the Atlantic and Gulf Rapid Reef Assessment (AGRRA) protocol (Ginsburg et al. 1998, Leão et al. 1999). After this training test, the methodology proposed in the AGRRA protocol was adopted by our group, in order to evaluate the present status of the Eastern Brazilian coral reefs and provide standards for future monitoring and conservation programs.

A survey of the reefs of the Abrolhos National Marine Park began in 2000. This survey included only the offshore reefs located within the park limits (Kikuchi et al. 2003 a, b), but in the following years (2001, 2002, 2003 and 2005) it was extended to the coastal bank reefs of all Abrolhos region, including an evaluation of sediment accumulation rate in the reefs (Dutra 2003, Dutra et al. 2006), and of the use of the Abrolhos Archipelago fringing reefs by tourists (Spanó et al. 2008).

Also, using the AGRRA protocol, in 2003 and 2004 reefs bordering Tinharé and Boipeba islands, and the ones located in the Cabrália area, were assessed. These reefs have been threatened, in recent time, by an accelerated coastal development particularly associated with tourism industry.

In 2003 the coral reefs located within Todos os Santos Bay were quantitatively assessed using an adaptation of the video-transect method (Dutra \& Kikuchi 2003) from the techniques proposed by Aronson \& Swanson (1997) and Page et al. (2001). The results were compared with data acquired by Laborel (1969) and they show a significant change in the reef coral and octocoral communities (Dutra et al. 2006) that may be due to the elevated water turbidity of the bay. Water quality analysis of the bay, which is impacted by the urban and industrial development surroundings, began about 50 years ago.

In early 2005, the condition of the Itacolomis reefs was also evaluated. These reefs mark the beginning of the occurrence of the giant mushrooms reef-coral pinnacles with a mushroom growth form-to the Southern coast 
of the state of Bahia. Isolated bank reefs separated from one another by irregular deep (10$15 \mathrm{~m})$ channels present in this region as well. During the same year, a new assessment was accomplished in the fringing reef located in the South shore of St. Barbara Island (Abrolhos Archipelago), where effects of impact by inadequate use of the reefs were observed in previous surveys.

During these surveys, studies comparing the biotic parameters of the Abrolhos reefs with sedimentation rates, showed that sediment accumulation rates, measured with sediment traps, are negatively related with the vitality of the reef biota. The average rate of sediment accumulation $>15 \mathrm{mg} / \mathrm{cm}^{2}$.day seemed to be detrimental for the vital condition of the reefs. The terrigenous content of sediment is also negatively related to the reef vitality (Dutra 2003, Dutra et al. 2006, \& Leão et al. 2005). Moreover, a three year monitoring of the fringing reefs that border the Abrolhos Archipelago islands (2000-2002), indicate that there is already coral damage in sites where intensive diving is permitted. Spanó et al. (2008) found that the number of visitors diving in the South shore of St. Barbara Island reached over 10000 persons per year, a number that it is considered high enough to be deleterious to reef's vitality (Hawkins \& Roberts 1997).

Taking all these findings into account, this work establishes the baseline of the current condition of the Eastern Brazil reefs, having the benthic organisms as indicators-corals and algae: the vitality of the major reef building corals, and the relative abundance of algal functional groups-macro, turf and crustose coralline. The analyzed data are from surveys that were conducted applying the methodology proposed in the Atlantic and Gulf Rapid Reef Assessment-AGRRA protocol. In most assessments the complete protocol was applied and, in few cases, it was partially adapted. The major goals of this work are, thus, to describe the spatial variations of the reef vitality indices and to evaluate if the indices display identifiable changes in reef conservation in the outset of the millennium.

\section{DESCRIPTION OF THE STUDIED REEF AREAS}

Regional setting: The continental shelf along the coast of the State of Bahia varies considerably in width. It is very narrow at its Northern limits with an average width of $50 \mathrm{~km}$, and, at its minimum reaches about $15 \mathrm{~km}$ off Tinharé and Boipeba islands. In its Southern portion, by contrary, particularly in the Abrolhos area, it widens circa $200 \mathrm{~km}$, forming the Royal Charlotte and the Abrolhos Bank. The shelf break is commonly at an average of $70 \mathrm{~m}$ depth. Carbonate sediments dominate the middle and the outer shelves. The inner shelf constitutes a typical mixed zone of siliciclastic and carbonate sediments; the siliciclastics originate from river discharges, coastal erosion and reworked relict deposits of former lower sea-level stands and the carbonates are locally produced grains by the growth and transport of calcareous organisms (Leão \& Ginsburg 1997, Leão \& Dominguez 2000).

Easterly and Southeasterly trade winds dominate in this part of the Atlantic Ocean, with speeds that rarely surpass $5.5 \mathrm{~m} / \mathrm{s}$ (US Navy 1978). A tropical humid climate dominates with less than two consecutive dry months. The sea surface temperature in this part of the ocean varies from $30^{\circ} \mathrm{C}$ during summer (February to May) to $25^{\circ} \mathrm{C}$ during winter (June to August). However, during winter minimum temperature can reach $21^{\circ} \mathrm{C}$ in the region of Abrolhos (US Navy 1978).

The Brazilian Current (BC) and the North Coastal Brazilian Current (NCBC) are the main surface currents along the Brazilian continental margin (Stramma 1991, Silveira et al. 1994). They originate from the Southern Equatorial Current at about $5^{\circ}$ and $6^{\circ} \mathrm{S}$ and flow to the South $(\mathrm{BC})$ with average velocities of 50 to $70 \mathrm{~cm} / \mathrm{s}$, and to the North and Northwest (NCBC) attaining velocities of $30 \mathrm{~cm} / \mathrm{s}$.

Along the coast of the State of Bahia Easterly waves dominate during the whole year. The Northeast waves are dominant from November to February (summer) and the Southeast waves, from March to August (winter). The 
tides are semi-diurnal, and classified as lower meso-tidal.

Reef types and distribution: According to a description given in Leão et al. (2003), coral reefs along the Eastern Brazilian coast occurs, from North to South, in six major reef areas: a) the North Coast of the State of Bahia, b) the Todos os Santos Bay, c) the Tinharé - Boipeba Islands and Camamu Bay, d) the Cabrália/Porto-Seguro area, e) the Itacolomis reefs, and f) the Abrolhos Reef complex (Fig. 1). Along the whole coast of the Bahia State, the poorest developed coral reefs are found in the North coast (NC) $\left(12^{\circ} 30^{\prime}-13^{\circ} 45^{\prime} \mathrm{S}\right)$ (Nolasco \& Leão 1986, Kikuchi \& Leão 1998, Kikuchi 2000). In Todos os Santos Bay (TSB) $\left(12^{\circ} 40^{\prime}-13^{\circ} 10^{\prime} \mathrm{S}\right)$, the second largest bay in Brazil (Lessa et al. 2000), fringing reefs border the shores of the islands in waters no deeper than 10m (Dutra et al. 2006). Surrounding the islands of Tinharé and Boipeba (TBC) (13\%20'$\left.14^{\circ} 05^{\prime} \mathrm{S}\right)$, there are fringing reefs and shallow bank reefs. In the Cabralia/Porto-Seguro area (CPS) $\left(16^{\circ} 05^{\prime}-16^{\circ} 40^{\prime} \mathrm{S}\right)$, shallow bank reefs, with varied shapes and dimensions, run parallel to the coastline. The Itacolomis reefs (16 $6^{\circ} 50^{\prime}-$ $\left.17^{\circ} 10^{\prime} \mathrm{S}\right)$ face the Corumbau Point, marking the beginning of the occurrence, from North Southward along the coast of Eastern Brazil, of the giant "Brazilian mushroom reefs-coral pinnacles" with a mushroom shape growth form. The Abrolhos Reef complex $\left(17^{\circ} 20^{\prime}-18^{\circ} 10^{\prime} \mathrm{S}\right)$ constitutes two major reef arcs: the coastal arc

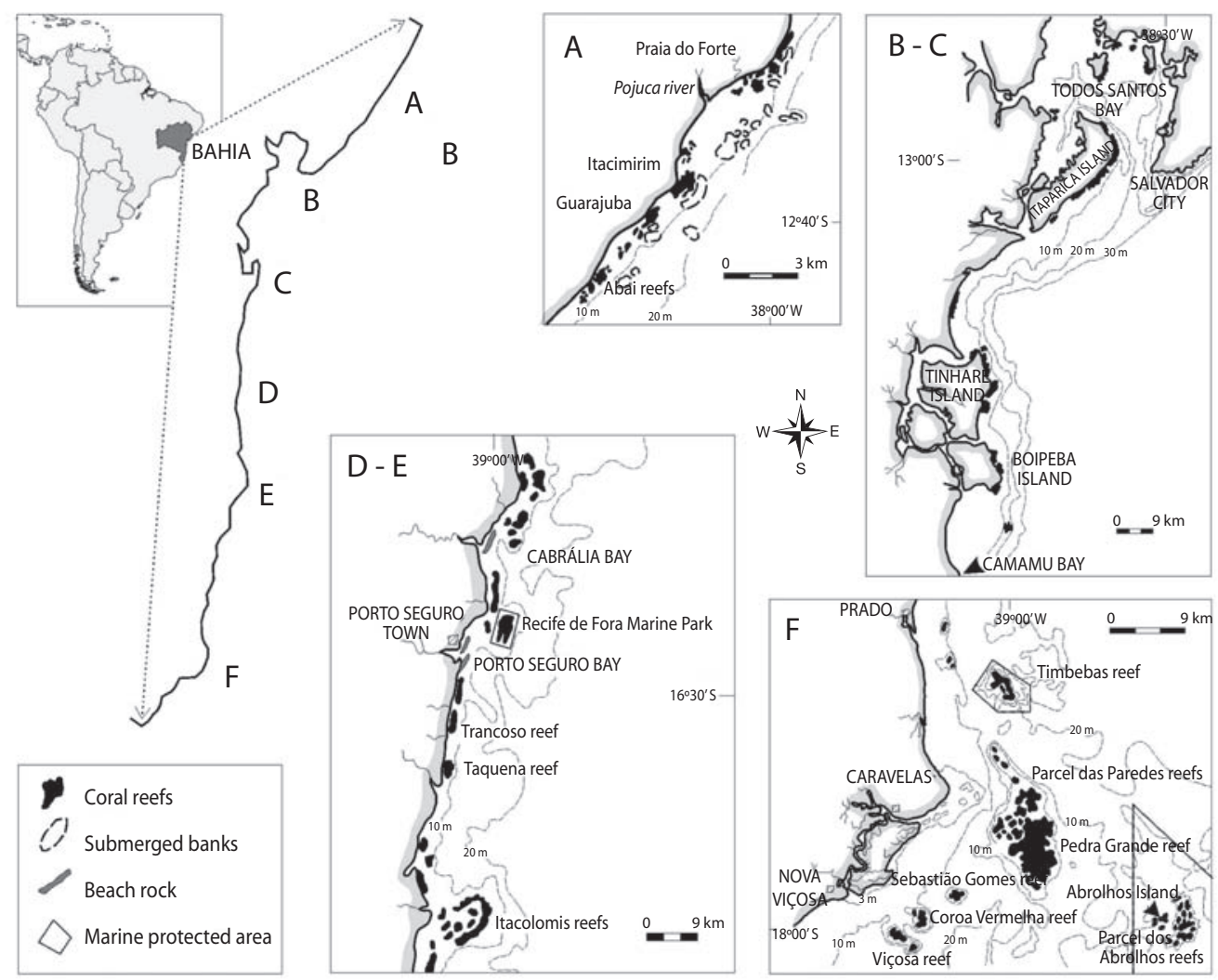

Fig. 1. Studied reefs location along the coast of the State of Bahia in Eastern Brazil. $A=$ The North Coast (NC) of the state. $\mathrm{B}=$ Todos os Santos Bay (TSB). C = Tinharé and Boipeba Islands and Camamu Bay (TBC). D= Cabrália and Porto Seguro area (CPS). $\mathrm{E}=$ Itacolomis Reefs (ITA). $\mathrm{F}=$ Abrolhos reef complex (ABR). 
that is composed by a complex of large reef structures formed by coalescent mushrooms reefs, usually surrounded by isolated ones, and the outer arc, that consists of isolated submerged giant mushroom reefs up to $50 \mathrm{~m}$ diameter, in water depths exceeding $20 \mathrm{~m}$. Fringing reefs border the rocky shores of the islands of the Abrolhos Archipelago. These are not remarkable coral constructions, but are rather a veneer of reef organisms, which extend from the lower water level to depths of about $5 \mathrm{~m}$.

Reef-building coral fauna: The stony coral fauna of Bahian region reefs has a very low diversity and a significant endemism. From the eighteen species that were earlier registered in the Brazilian coast, sixteen are found in the Abrolhos reefs. The number of coral species reduces from the Abrolhos region Northward (Table 1) (Laborel 1969, 1970, Belém et al. 1986, Leão 1982, Araújo 1984, Nolasco 1987, Castro 1994). Six species of the reef building coral fauna are endemic species of the Western South Atlantic waters. Among these some have affinities with Caribbean coral forms and some are remnants of a more resistant relict fauna dating back the Tertiary time, which was probably preserved during Pleistocene sea level low stands, in a refuge provided by the sea-mountains off the Abrolhos Bank (Leão 1983). These archaic species are the most common forms in all studied reefs. They are the three species of the genus Mussismilia: M. braziliensis (Verrill, 1868), M. hispida (Verrill, 1868) and M. harttii (Verrill, 1868) and the species Favia leptophylla (Verrill, 1868). The other two endemic species are F. gravida (Verrill, 1868) and Siderastrea stellata (Verrill, 1868), both related to the Caribbean coral fauna.

The species M. braziliensis and F. leptophylla are the Brazilian corals that show the greatest geographical confinement, because they are, so far, found only along the coast of the state of Bahia. The species S. stellata and $F$. gravida have a broader distribution along the coast of Brazil, and are the most common corals in the shallow intertidal pools of reef tops. These latter species are very resistant to variations in temperature, salinity and water turbidity.

The cosmopolitan species Porites astreoides (Lamark, 1859), P. branneri (Rathbun, 1887), Agaricia agaricites (Linne, 1758), A. fragilis (Dana, 1846), Stephanocoenia michelinii (Milne Edwards \& Haime, 1848) and Madracis decactis (Lymann, 1859) have a secondary role in the building-up of the reefs in Bahia. The species Montastraea cavernosa (Linne, 1766) is an abundant species in some patch reefs inside Todos os Santos Bay. The small corals Scolymia wellsi (Laborel, 1967) and Astrangia braziliensis (Vaughan, 1906),

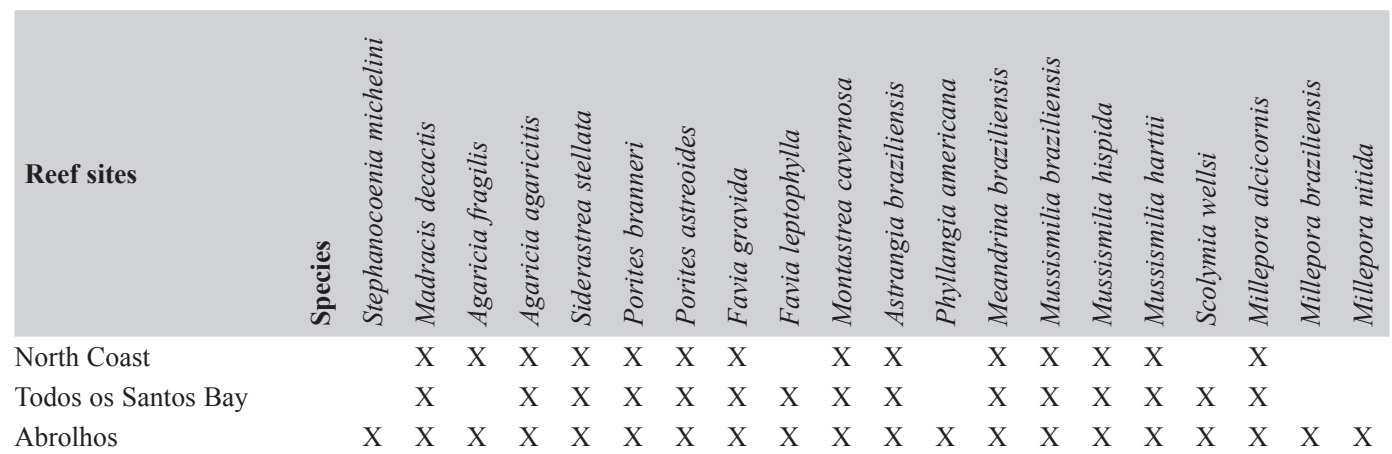


which are commonly found in cryptic habits, do not contribute significantly to the reef structure. More recently Neves (2004) added the species Siderastrea radians (Pallas, 1766) and S. siderea (Ellis \& Solander, 1876) to the coral fauna found in Brazilian waters.

The distribution of these reef-building coral fauna on the reef tops and walls varies between the shallow bank reefs and the giant offshore mushroom reefs. On the top of the small mushroom reefs that surround the nearshore bank reefs it is commonly seen, at a flat surface that occur at a depth of 4 to $5 \mathrm{~m}$, dead coral colonies covered by Palythoa sp. The major corals growing in these small coral pinnacles are the three species of the genus Mussismilia and few colonies of Siderastrea sp. Millepora alcicornis grows on the borders of these small mushroom reefs, and reef walls are mostly bared of corals (Fig. 2 A).

The isolated offshore mushroom reefs that occur at the outer arc of reefs of Abrolhos can reach a height of about $25 \mathrm{~m}$ with a surface area that has a diameter of approximately $50 \mathrm{~m}$. On the top of these mushroom reefs millepores surround central areas of corals. These central areas consist mostly of large columns of Mussismilia braziliensis, which can reach heights up to $2 \mathrm{~m}$ and can be topped with a living colony having a diameter of approximately $1 \mathrm{~m}$. Between these columns, there are heads of Favia leptophylla, Mussismilia hispida, Siderastrea stellata and small colonies of Porites asteroides. The vertical walls of these mushroom reefs are covered by corals that show a zonation from photophile forms in its upper parts (e.g. Mussismilia hispida, M. harttii, Siderastrea stellata, Favia gravida) to the shade-loving species (sciaphile), which attain maximum development under the overhangs (e.g. Agaricia fragilis, Scolymia wellsi) (Fig. 2 B).

\section{MATERIAL AND METHODS}

Reef survey: The present work presents the data from reefs surveyed using the AGRRA method, except for the reefs from the North
Coast. The AGRRA protocol is described, in details, at the web-page http://www.agrra. org (Ginsburg et al. 1998), updated in 2005. The assessment of coral status is performed along six $10 \mathrm{~m}$ long transects, where the line intercept method is applied for coral cover. Colony diameter, dead surfaces, bleaching and diseases are analyzed in a belt $1 \mathrm{~m}$ wide along the line transects. Five quadrats $(25 \mathrm{~cm} x$ $25 \mathrm{~cm}$ ) per transect are used for estimating the relative abundance of algal types: macro, turf $(\leq 1 \mathrm{~cm}$ high), and crustose corallines. Within the quadrat, average canopy height of macroalgae is estimated, and number of coral recruits (colonies $\leq 2 \mathrm{~cm}$ ) is counted. AGRRA originally established the $25 \mathrm{~cm}$ as the minimum diameter for the surveyed coral colonies, but because in most surveyed reefs of Bahia, coral colonies rarely attain larger sizes, we changed to $20 \mathrm{~cm}$ as minimum size for the coral colonies to be counted. No coral disease was observed in the corals from the reefs of Bahia during our surveys, but later in 2005 first occurrence of disease was seen affecting colonies of the endemic coral Mussismilia braziliensis in the Abrolhos reefs (Francini-Filho et al. 2008). Diadema antillarum was very rare in the surveyed reef sites.

Following the purpose of AGRRA for defining what is a region, an area, a reef and a site, we consider the Bahia state as a coral reef region, with six distinct areas, from North to South: A. the North Coast of the State, B. the Todos os Santos Bay, C. the Tinharé/Boipeba/ Camamu area, D. the Cabrália and PortoSeguro area, E. the Itacolomis reefs and F. the Abrolhos reef complex (Figure 1).

The reefs of the North Coast were assessed before the development of the AGRRA protocol. Three bank reefs (Guarajuba, Itacimirim and Praia do Forte) were surveyed using $1 \mathrm{~m}$ wide belt transect, $20 \mathrm{~m}$ long at depths varying between $4.5,8.5 \mathrm{~m}$, and where coral cover, species richness, size of the coral colonies and density of coral recruits were measured (Leão et al. 1997, Kikuchi \& Leão 1998, Kikuchi 2000, Leão \& Kikuchi 2005) (Table 2). 


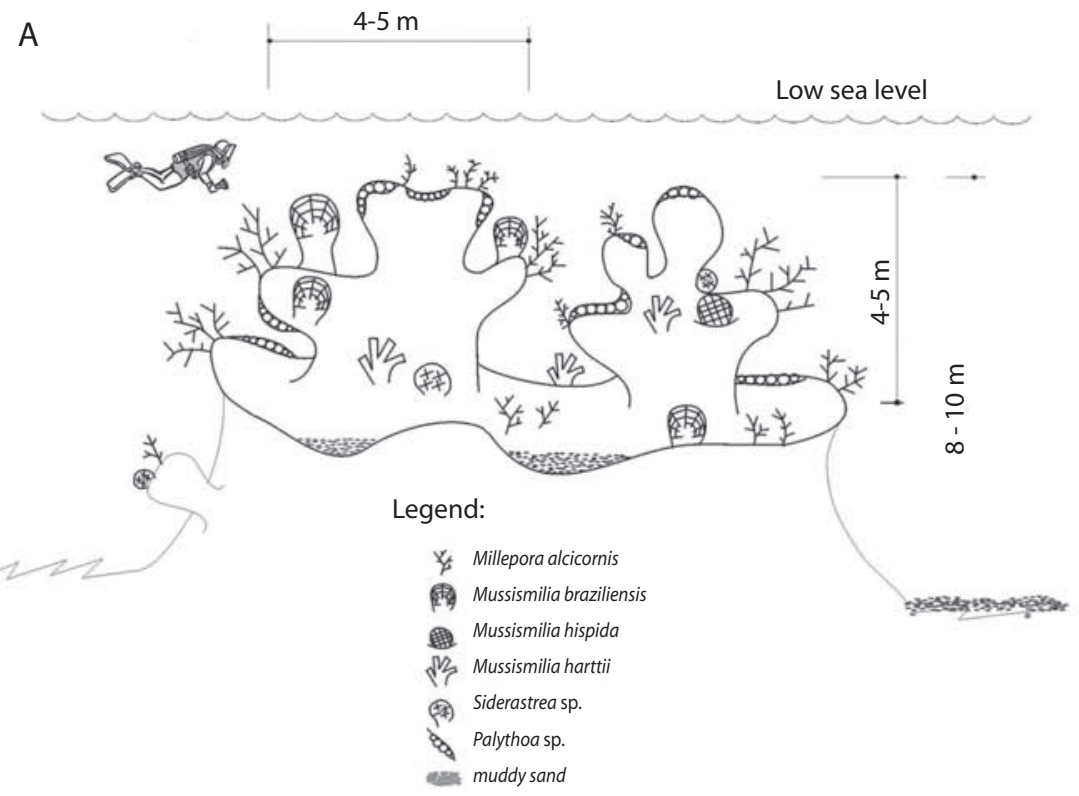

B

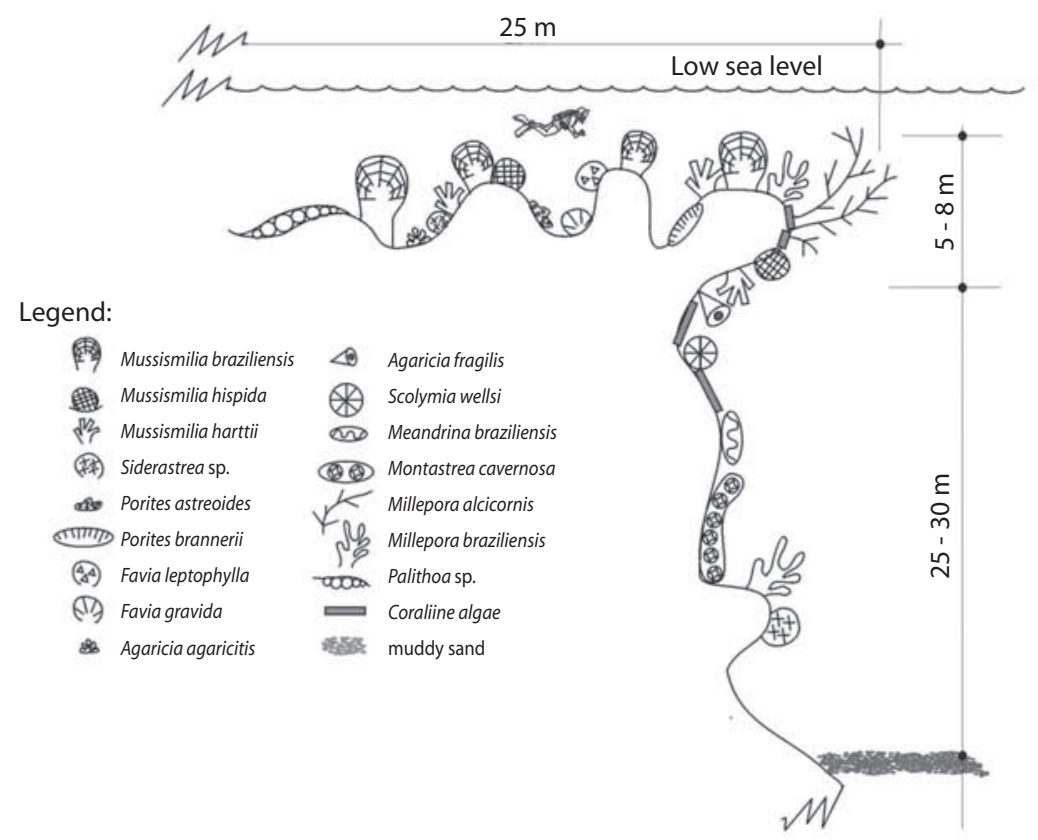

Fig. 2. Sketches of Brazilian mushroom reefs (coral pinnacles with a mushroom growth form). A- a small mushroom reef from the coastal arc of reefs of Abrolhos that is commonly found surrounding larger bank reefs. B- a giant mushroom reef of the outer arc of reefs-the Parcel dos Abrolhos. 
TABLE 2

Reef site information of nearshore reefs $(<5 \mathrm{~km}$ off the coast) from the State of Bahia, in Eastern Brazil. Shallow $\leq 5 \mathrm{~m}$. Deep $>5 \mathrm{~m}$ ( $n=$ number of sites)

\begin{tabular}{|c|c|c|c|c|c|c|}
\hline Reef name & Lat. $\left({ }^{\circ} \mathrm{S}\right) /$ Long. $\left({ }^{\circ} \mathrm{W}\right)$ & Reef Site & $\begin{array}{l}\text { Site } \\
\text { code }\end{array}$ & Reef type & $\begin{array}{c}\text { Date } \\
\text { of survey }\end{array}$ & $\begin{array}{c}\text { Mean } \\
\text { Depth (m) }\end{array}$ \\
\hline North coast & $12.3805^{\circ} \mathrm{S} / 38.0200^{\circ} \mathrm{W}$ & Praia do Forte 1 & PFO1 & shallow bank & 1998 & 5.0 \\
\hline \multirow{5}{*}{$\mathrm{n}=6$} & & Praia do Forte 2 & $\mathrm{PFO} 2$ & deep bank & 1998 & 8.5 \\
\hline & & Itacimirim 1 & ITM1 & shallow bank & 1998 & 5.0 \\
\hline & & Itacimirim 2 & ITM2 & deep bank & 1998 & 8.5 \\
\hline & & Guarajuba 1 & GUA1 & shallow bank & 1998 & 4.5 \\
\hline & & Guarajuba 2 & GUA2 & deep bank & 1998 & 8.5 \\
\hline Tinhare-Boipeba & $13.4910^{\circ} \mathrm{S} / 38.9024^{\circ} \mathrm{W}$ & Praia do Quadro & PQUA & shallow bank & May 2003 & 3.6 \\
\hline \multirow[t]{3}{*}{$\mathrm{n}=4$} & & Garapua & GAR & shallow bank & May 2003 & 3.9 \\
\hline & & Morere & MOR & shallow bank & May 2003 & 4.0 \\
\hline & & Bainema & BAI & shallow bank & May 2003 & 3.9 \\
\hline Cabralia & $16.2397^{\circ} \mathrm{S} / 38.9526^{\circ} \mathrm{W}$ & Arajipe & ARA & deep bank & Sept 2004 & 6.8 \\
\hline \multirow[t]{5}{*}{$\mathrm{n}=6$} & & Coroa Alta N & CAN & shallow bank & Sept 2004 & 5.0 \\
\hline & & Coroa Alta S & CAS & shallow bank & Sept 2004 & 5.0 \\
\hline & & Itassepanema & ITA & shallow bank & Sept 2004 & 4.8 \\
\hline & & Alagadas & ALA & shallow bank & Sept 2004 & 4.9 \\
\hline & & Naufragio & NAU & shallow bank & Oct 2004 & 4.8 \\
\hline
\end{tabular}

In the Tinharé/Boipeba/Camamu area four reef sites (Praia do Quadro, Garapuá, Moreré and Bainema) were assessed during the year of 2003, applying the second version of the AGRRA protocol. In each reef site, six benthic transects (10m long), in depth around $4 \mathrm{~m}$, were used for measuring coral parameters; and 30 quadrats $(25 \mathrm{~cm} \times 25 \mathrm{~cm})$ were applied for the survey of algal types and density of coral recruits (Table 2).

Six sites of the Cabrália reefs (Arajipe, Coroa Alta Norte, Coroa Alta Sul, Itassepanema, Alagadas and Naufrágio) were assessed during the year of 2004, applying the same number of transects and quadrats as in the Tinharé/Boipeba survey, in depth ranging from around 5 to $7 \mathrm{~m}$ (Table 2).

Three sites of the Itacolomis reefs (Canudos, Pedra do Silva and Pedra do Cavalo) were evaluated at depths between $2.0 \mathrm{~m}, 3.5 \mathrm{~m}$ following the methodology already described for the previous reefs (Table 3 ).

The Abrolhos reef complex comprises coastal and offshore reefs. In the coastal arc of reefs the surveys were performed on the top of small mushroom reefs that surrounded larger exposed bank reefs. The submerged tops of these mushroom reefs are in areas shallower than $6 \mathrm{~m}$, where the major reef builder organisms grow. In greater depths of the reef walls corals are very rare (Fig. 2 A). In the offshore giant mushroom reefs that form the outer arc of reefs, the assessment was also conducted on their tops, which occur in depths between 6 and $10 \mathrm{~m}$ (Fig. 2 B). Because the lateral walls of these pinnacles are mostly inhabited by small coral colonies (such as Agaricia fragilis, Scolymia wellsi, Meandrina braziliensis) that do not have great importance as reef builders, they were not assessed.

During the 2000 survey, the AGRRA protocol was applied in the offshore reefs located inside the Abrolhos National Marine Park. Eight sites were located in three fringing reefs bordering the North (3 sites), the West (2 sites) and the South (3 sites) shores of St. Barbara Island, in water depths varying from $3.5 \mathrm{~m}$ to $5.0 \mathrm{~m}$. Five sites were located at the top of the pinnacles of the Parcel dos Abrolhos in depths varying from 6 to $9 \mathrm{~m}$ (Table 3). Ten benthic 
TABLE 3

Reef site information of offshore reefs ( $>5 \mathrm{~km}$ off the coast) from the State of Bahia, in Eastern Brazil. Shallow $\leq 5 \mathrm{~m}$. Deep $>5 m$ ( $n=$ number of sites)

\begin{tabular}{|c|c|c|c|c|c|c|}
\hline Reef name & $\begin{array}{l}\left.\text { Lat. ( }{ }^{\circ} \mathrm{S}\right) / \text { Long. } \\
\quad\left({ }^{\circ} \mathrm{W}\right)\end{array}$ & Reef site & $\begin{array}{l}\text { Site } \\
\text { code }\end{array}$ & $\begin{array}{l}\text { Reef } \\
\text { type }\end{array}$ & Date of survey & $\begin{array}{c}\text { Mean } \\
\text { depth (m) }\end{array}$ \\
\hline Itacolomis & $16.8976^{\circ} \mathrm{S} /$ & Pedra do Cavalo & PCA & shallow mushroom reef & April 2005 & 2.0 \\
\hline \multirow[t]{2}{*}{$\mathrm{n}=3$} & \multirow[t]{2}{*}{$39.0909^{\circ} \mathrm{W}$} & Pedra do Silva & PSI & shallow mushroom reef & April 2005 & 2.5 \\
\hline & & Canudos & CAN & shallow mushroom reef & April 2005 & 3.5 \\
\hline \multirow{5}{*}{$\begin{array}{l}\text { Timbebas } \\
n=5\end{array}$} & \multirow{5}{*}{$\begin{array}{l}17.4660^{\circ} \mathrm{S} / \\
39.0094^{\circ} \mathrm{W}\end{array}$} & Timbebas 1 & TIM1 & shallow mushroom reef & Mar2001/02/03 & 4.5 \\
\hline & & Timbebas 2 & TIM2 & shallow mushroom reef & Mar2001/02 & 4.0 \\
\hline & & Timbebas 3 & TIM3 & shallow mushroom reef & Mar2001/02 & 4.0 \\
\hline & & Timbebas 4 & TIM4 & shallow mushroom reef & Mar2001/02 & 5.5 \\
\hline & & Timbebas 5 & TIM5 & shallow mushroom reef & Mar2001/02 & 6.0 \\
\hline \multirow{5}{*}{$\begin{array}{l}\text { Lixa } \\
n=5\end{array}$} & \multirow{5}{*}{$\begin{array}{l}17.6630^{\circ} \mathrm{S} / \\
38.9595^{\circ} \mathrm{W}\end{array}$} & Lixa 1 & LIX1 & shallow mushroom reef & Mar2001/02/03 & 5.5 \\
\hline & & Lixa 2 & LIX2 & shallow mushroom reef & Mar2001/02 & 4.5 \\
\hline & & Lixa 3 & LIX3 & shallow mushroom reef & Mar2001/02 & 4.5 \\
\hline & & Lixa 4 & LIX4 & shallow mushroom reef & Mar2001/02 & 3.5 \\
\hline & & Lixa 5 & LIX5 & shallow mushroom reef & Mar2001/02 & 2.5 \\
\hline \multirow{2}{*}{$\begin{array}{l}\text { Pedra de Leste } \\
n=2\end{array}$} & $17.7755^{\circ} \mathrm{S} /$ & Leste 1 & LES1 & shallow mushroom reef & Mar 2002 & 1.0 \\
\hline & $39,0508^{\circ}{ }^{\circ} \mathrm{W}$ & Leste 2 & LES2 & shallow mushroom reef & Mar 2002 & 2.5 \\
\hline \multirow{5}{*}{$\begin{array}{l}\text { Paredes Sul } \\
\mathrm{n}=5\end{array}$} & $17.9004{ }^{\circ} \mathrm{S} /$ & Paredes S1 & PAR1 & shallow mushroom reef & Mar 2001/02 & 5.0 \\
\hline & $38.9092^{\circ} \mathrm{W}$ & Paredes S2 & PAR2 & shallow mushroom reef & Mar 2001/02 & 5.0 \\
\hline & & Paredes S3 & PAR3 & shallow mushroom reef & Mar 2001/02 & 4.0 \\
\hline & & Paredes S4 & PAR4 & shallow mushroom reef & Mar 2001/02 & 2.0 \\
\hline & & Paredes S5 & PAR5 & shallow mushroom reef & Mar 2001/02 & 5.0 \\
\hline \multirow{5}{*}{$\begin{array}{l}\text { Popa Verde } \\
n=5\end{array}$} & $18.0203^{\circ} \mathrm{S} /$ & Popa Verde1 & POP1 & deep mushroom reef & Mar 2002 & 5.5 \\
\hline & $38.9883^{\circ} \mathrm{W}$ & Popa Verde2 & POP2 & deep mushroom reef & Mar 2002 & 6.0 \\
\hline & & Popa Verde3 & POP3 & deep mushroom reef & Mar 2002 & 7.0 \\
\hline & & Popa Verde4 & POP4 & deep mushroom reef & Mar 2002 & 7.5 \\
\hline & & Popa Verde5 & POP5 & deep mushroom reef & Mar 2002 & 8.0 \\
\hline \multirow{3}{*}{$\begin{array}{l}\text { St. Barbara Is N } \\
\mathrm{n}=3\end{array}$} & $17.9673{ }^{\circ} \mathrm{S} /$ & St Barbara N1 & SBN1 & shallow fringing & Mar 2000/01/02/05 & 4.0 \\
\hline & $38,7018^{\circ} \mathrm{W}$ & St Barbara N2 & SBN2 & shallow fringing & Mar2000 & 4.5 \\
\hline & & St Barbara N3 & SBN3 & shallow fringing & Mar 2000 & 3.5 \\
\hline \multirow{5}{*}{$\begin{array}{l}\text { St. Barbara Is W } \\
\mathrm{n}=2 \\
\text { St. Barbara Is } \mathrm{S} \\
\mathrm{n}=3\end{array}$} & $17.9641^{\circ} \mathrm{S} /$ & St Barbara W1 & SBW1 & shallow fringing & Mar 2000/01 & 3.5 \\
\hline & $38.7066^{\circ} \mathrm{W}$ & St Barbara W2 & SBW2 & shallow fringing & Mar 2000 & 4.5 \\
\hline & $17.9815^{\circ} \mathrm{S} /$ & St Barbara S1 & SBS1 & shallow fringing & Mar 2000/01/02/05 & 4.0 \\
\hline & $38.7036^{\circ} \mathrm{W}$ & St Barbara S2 & SBS2 & shallow fringing & Mar 2000/01 & 5.0 \\
\hline & & St Barbara S3 & SBS3 & shallow fringing & Mar 2000 & 5.0 \\
\hline \multirow{2}{*}{$\begin{array}{l}\text { Guarita Is. } \\
\mathrm{n}=1\end{array}$} & $17.9602^{\circ} \mathrm{S} /$ & Guarita & GUA & shallow fringing & Mar 2002 & 4.5 \\
\hline & $38.6922^{\circ} \mathrm{W}$ & & & & & \\
\hline \multirow{2}{*}{$\begin{array}{l}\text { Redonda Is. } \\
\mathrm{n}=1\end{array}$} & $17.9634^{\circ} \mathrm{S} /$ & Redonda & RED & shallow fringing & Mar 2001/02 & 3.5 \\
\hline & $38.7083^{\circ} \mathrm{W}$ & & & & & \\
\hline \multirow{2}{*}{$\begin{array}{l}\text { Siriba Is. } \\
n=1\end{array}$} & $17.9697^{\circ} \mathrm{S} /$ & Siriba & SIR & deep fringing & May 2005 & 6.5 \\
\hline & $38.7101^{\circ} \mathrm{W}$ & & & & & \\
\hline \multirow{2}{*}{$\begin{array}{l}\text { Sueste Is. } \\
\mathrm{n}=1\end{array}$} & $17.9794{ }^{\circ} \mathrm{S} /$ & Sueste & SUE & deep fringing & Mar 2001 & 8.0 \\
\hline & $38.7080^{\circ} \mathrm{W}$ & & & & & \\
\hline \multirow{2}{*}{$\begin{array}{l}\text { Parcel dos } \\
\text { Abrolhos }\end{array}$} & $17.9977^{\circ} \mathrm{S} /$ & Parcel Abrolhos1 & PAB1 & deep mushroom reef & Mar 2001/02 & 6.0 \\
\hline & & & & & & \\
\hline \multirow[t]{5}{*}{$\mathrm{n}=6$} & $38.6713^{\circ} \mathrm{W}$ & Parcel Abrolhos2 & PAB2 & deep mushroom reef & Mar 2000/01/02 & 7.0 \\
\hline & & Parcel Abrolhos3 & PAB3 & deep mushroom reef & Mar 2000/01/02 & 7.0 \\
\hline & & Parcel Abrolhos4 & PAB4 & deep mushroom reef & Mar 2000/01/02/03 & 7.0 \\
\hline & & Parcel Abrolhos5 & PAB5 & deep mushroom reef & Mar 2000/01/02 & 8.0 \\
\hline & & Parcel Abrolhos6 & PAB6 & deep mushroom reef & Mar 2000/01/02 & 9.0 \\
\hline
\end{tabular}


transects were surveyed in the offshore pinnacles, but in the fringing reefs their numbers varied from 10 to 15 per site. The total number of quadrats varied among the analyzed reefs, from 50 to 75 (Kikuchi et al. 2003a, b). Coral cover, number and size of coral species, recent and old mortality, and density of coral recruits were also considered.

In 2001, the survey of Abrolhos reefs extended to the coastal zone where three reefs were assessed (Timbebas- 5 sites, Lixa-5 sites and Paredes-5 sites) in depths varying from 2.5 to $6 \mathrm{~m}$. One more fringing reef of the Abrolhos Archipelago was added to the reefs surveyed in 2000-the Sueste Island, where one site was surveyed at a depth of $8 \mathrm{~m}$ (Table 3). In all reef sites, six benthic transects were completed, and 30 quadrates were used to measure the algal relative abundance and density of coral recruits.

In 2002, the AGRRA protocol was applied in five fringing reefs bordering the islands of the Abrolhos Archipelago-the St. Barbara Island (North coast-2 sites, West coast-2 sites, South coast-2 sites), the Guarita island (1 site) and Redonda Island (1 site); in six sites in the mushroom reefs of the Parcel dos Abrolhos, and in other four coastal reefs: the Timbebas reef ( 5 sites), the Lixa reef ( 5 sites), the Paredes reef ( 5 sites) and the Popa Verde reef ( 5 sites), adding a total number of 34 analyzed reef sites. In each site the protocol was applied with six $10 \mathrm{~m}$ long benthic transects and 30 quadrates for measurement of coral and algae parameters (Table 3).

During the year of 2003, only three reefs of the Abrolhos region were surveyed for coral bleaching. For Timbebas and Lixa coastal reefs four benthic transects were measured per reef site at depths between 5 and $6 \mathrm{~m}$. For the offshore coral pinnacles of the Parcel dos Abrolhos, six benthic transects were applied in five sites located at the top of the mushroom reefs, in depths averaging $6.5 \mathrm{~m}$ (Table 3 ).

Three reef sites were evaluated in Abrolhos, after the occurrence of an ocean water temperature anomaly in early 2005 (FebruaryMarch, end of summer): the North and the
South shores of St. Barbara and Siriba Islands. At each fringing reef of St. Barbara Island four $10 \mathrm{~m}$ long transects and 30 quadrates were used to evaluate coral and algae condition, and six transect with 30 quadrates were used to assess the fringing reef of Siriba Island, for the first time (Table 3).

For statistical analysis, we seek both spatial (geographical) and temporal patterns in reef data and multivariate analysis techniques were used. For the spatial approach, an ordination of the reef sites by the AGRRA indices was made, using the non-metric multidimensional scaling (MDS) technique, based on Bray-Curtis similarity indices matrix. Because the indices have different nature and scales, they were standardized by row, this means that each index was divided by the maximum value of that index in all sites and multiplied by 100 . A second step was to analyze similarities between reef regions and between nearshore and offshore reefs, by testing the null hypothesis of no differences across regions and/or distance from the coast, with ANOSIM (Analysis of Similarity) and the closeness of the indices using SIMPER (Similarity Percentages) (Clarke \& Warwick 1994). We used the 2002 survey data from Abrolhos in this analysis.

The data series of Abrolhos region reefs (2000 to 2002) was submitted to similar treatments. We compared sites of each yearly survey based on a Bray-Curtis similarity indices matrix calculated with standardized data. Initially we applied an ordination using the MDS technique and, afterwards, the tests Analysis of Similarity (two-way nested layout, with years as "treatment" category) and Similarity Percentages to verify if there were differences among the successive yearly surveys.

The reefs studied in the Brazilian East coast, also named Southwest Atlantic reefs, were compared with the reefs of the Northwest Atlantic Ocean surveyed with AGRRA protocol, using data from Kramer (2003). For this analysis we took into account five coral indicators: live stony coral cover, density of coral recruits (number of individuals $/ \mathrm{m}^{2}$ ), percentage of old and recent partial mortality and 
percentage of bleached coral colonies. Reefs were grouped as nearshore, offshore (Southwest Atlantic reefs) and North Atlantic reefs. The same multivariate approach (ordination, ANOSIM test and SIMPER test) was applied. PRIMER software package version 6.1 .10 was used.

\section{RESULTS}

The condition of the reefs from the North coast of the State: The 1998 three reef sites survey in the North coast revealed, that the average coral cover on the top of submerged reefs ranged from $0.7 \pm 0.1 \%$ to $2.4 \pm 1.6 \%$, the number of coral colonies with diameter higher than $20 \mathrm{~cm}$ was very low ( $<2$ corals per site), and the average size of the colonies, counting the total number of colonies, was less than $7 \mathrm{~cm}$ diameter. Additionally, the density of coral recruits was very low $\left(<1 / \mathrm{m}^{2}\right)$, and no coral bleaching was observed during the survey (Table 4). All this previous work indicated a total of thirteen coral species and one milleporid for the Bahia coast (see Table 1) (Kikuchi \& Leão 1998, Kikuchi 2000).

The coral survey of the reefs from Tinharé/Boipeba/Camamu area: Four reef sites selected in the reefs bordering the coast of the islands of Tinharé and Boipeba were assessed in the summer 2003. Coral colonies with diameter over $20 \mathrm{~cm}$ were considered. Live coral cover attained $5.3 \pm 2.6 \%$ in one site, but did not reach $3 \%$ in the other surveyed reefs. Partial old mortality ranged from $10.0 \pm 0.0 \%$ to $13.0 \pm 12.5 \%$, whereas recent death varied from $5.0 \pm 0.0 \%$ to $10.0 \pm 0.0 \%$, and coral bleaching, attained numbers between 12 and $23 \%$. The number of recruits per square meter was very low ( $\leq 5$ individuals $\left./ \mathrm{m}^{2}\right)$. Macro and turf algae dominate over corallines (Table 4).

The reefs along the coast of Cabrália/ Porto-Seguro: Live stony coral cover varied between $2.3 \pm 0.4 \%$ and $9.4 \pm 1.4 \%$, old partial mortality reached values higher than $30 \%$

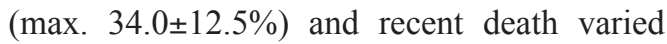

between zero and $20 \%$. Coral recruitment was very low (maximum 3.0 individuals $/ \mathrm{m}^{2}$ ) and coral bleaching was not observed at this time of the year of survey. The relative abundance of the macro algae presented percentages up to $62.3 \pm 27.1 \%$, higher than turf $(28.1 \pm 25.5 \%$ to $43.8 \pm 29.0 \%)$ and corallines $(7.9 \pm 9.7 \%$ to $35.4 \pm 29.6 \%$ ) (Table 4).

The monitoring program of the reefs from the Abrolhos area: Data from the 2000 survey, revealed that the average live stony coral cover in the shallow $(<5 \mathrm{~m})$ fringing reefs of St. Barbara Island varied from $5.9 \pm 2.2 \%$ to $9.7 \pm 3.0 \%$; the lowest value was found in the reefs that border the South shore of St. Barbara Island, where the lowest coral colonies density (44.6 \pm 12.8 individuals in the site) was found. In the offshore mushroom reefs the average coral cover reached values up to $20 \%$. The average of recent death corals varied from $2.7 \pm 0.1 \%$ to $4.5 \pm 1.3 \%$ in the fringing reefs, and reached $5.6 \pm 0.8 \%$ in the offshore coral pinnacles. On the other side, old mortality has almost similar results in all surveyed reefs (varying from a mean value $20.5 \pm 2.0 \%$ to $24.3 \pm 10.1 \%$ in the fringing reefs, and in the offshore mushroom reefs of $20.5 \pm 2.0 \%$ ). Coral bleaching is less than $4 \%$ in all investigated reefs. The number of coral recruits per square meter varied from $10.3 \pm 2.7$ to $16.6 \pm 11.7$ recruits $/ \mathrm{m}^{2}$ in the fringing reefs, and was over 37 recruits $/ \mathrm{m}^{2}$ in the offshore mushroom reefs. Turf algae dominate in all reefs with percentages over $65 \%$ (Table 5).

During the 2001 survey, live stony coral cover in the fringing reefs of St. Barbara Island varied from $8.1 \pm 0.3 \%$ to $15.4 \pm 4.4 \%$, and the lowest values were found again in the fringing reefs of the South shore of St. Barbara Island where the density of coral colonies was, also, the lowest one $(79.0 \pm 1.4$ corals in the site). In the Redonda and Sueste islands reefs, surveyed for the first time, the data obtained were similar to the St. Barbara Island reefs: coral cover varied from $13.8 \pm 2.8 \%$ to $17.3 \pm 4.8 \%$, a density of corals $>20 \mathrm{~cm}$ reached values over 80 individuals per site, the coral recruits density ranged 
TABLE 4

Coral and algae condition of nearshore reefs ( $<5 \mathrm{~km}$ off the coast) from the state of Bahia, in Eastern Brazil. Coral parameters measured along six (10m long) transects at each reef site, density of coral recruits and algae characteristics recorded in $30(0.25 \mathrm{~cm})$ quadrats per transect. *Coral parameters measured using $1 \mathrm{~m}$ wide belt transect $20 \mathrm{~m}$ long, data averaged from reef sites. Mean and standard deviation

\begin{tabular}{lccccccc} 
Reef area & \multicolumn{3}{c}{ North Coast* } & \multicolumn{5}{c}{ Tinharé/ Boipeba } \\
Reef name & Praia do Forte & Itacimirim & Guarajuba & $\begin{array}{c}\text { Praia do } \\
\text { Quadro }\end{array}$ & Garapua & Morere & Bainema \\
Number reef sites & 2 & 2 & 2 & 1 & 1 & 1 & 1 \\
Coral cover \% & $2.4 \pm 1.6$ & $0.7 \pm 0.1$ & $0.8 \pm 0.1$ & $2.7 \pm 1.3$ & $5.3 \pm 2.6$ & $2.8 \pm 1.4$ & $2.0 \pm 0.7$ \\
Corals $>$ 20cm (\#./site, $60 \mathrm{~m}^{-2}$ ) & $1.0 \pm 1.4$ & $2.0 \pm 0.08$ & $1.0 \pm 0.0$ & $25.0 \pm 0.0$ & $32.0 \pm 0.0$ & $13.0 \pm 0.0$ & $13.0 \pm 0.0$ \\
Colony size (cm) & $5.8 \pm 0.4$ & $7.0 \pm 0.0$ & $6.8 \pm 1.1$ & $23.5 \pm 4.0$ & $22.0 \pm 4.5$ & $28.0 \pm 10.0$ & $24.0 \pm 7.0$ \\
Number of coral species & $0.5 \pm 0.7$ & $1.0 \pm 0.0$ & $1.0 \pm 0.0$ & $4.0 \pm 0.0$ & $5.0 \pm 0.0$ & $6.0 \pm 0.0$ & $4.0 \pm 0.0$ \\
Coral recruits (\#.m-) & $0.8 \pm 0.4$ & $0.1 \pm 0.0$ & $0.8 \pm 0.4$ & $5.0 \pm 0.0$ & $5.0 \pm 0.0$ & $2.0 \pm 0.0$ & $2.0 \pm 0.0$ \\
Recent death (\%) & - & - & - & $5.0 \pm 0.0$ & $5.0 \pm 0.0$ & $5.0 \pm 0.0$ & $10.0 \pm 0.0$ \\
Old mortality (\%) & - & - & - & $13.0 \pm 12.5$ & $11.0 \pm 10.5$ & $10.0 \pm 0.0$ & $10.0 \pm 3.5$ \\
Bleached colonies (\%) & - & - & - & $12.0 \pm 0.0$ & $19.0 \pm 0.0$ & $23.0 \pm 0.0$ & $23.0 \pm 0.0$ \\
Macro algae (\%) & - & - & - & $39.8 \pm 31.7$ & $29.9 \pm 37.7$ & $51.6 \pm 33.7$ & $46.2 \pm 27.5$ \\
Turf algae (\%) & - & - & - & $41.1 \pm 26.9$ & $47.3 \pm 43.6$ & $28.1 \pm 25.5$ & $36.4 \pm 22.3$ \\
Coralline algae (\%) & - & - & - & $19.2 \pm 16.2$ & $22.7 \pm 26.1$ & $20.3 \pm 19.8$ & $17.3 \pm 18.3$ \\
Macro canopy height $(\mathrm{cm})$ & - & - & - & $1.6 \pm 1.5$ & $1.0 \pm 1.6$ & $1.7 \pm 1.6$ & $0.4 \pm 0.7$ \\
Macroalgal index & - & - & - & 51.7 & 36.9 & 82.5 & 50.4
\end{tabular}

\begin{tabular}{lcccccc} 
Reef area & \multicolumn{7}{c}{ Cabralia } \\
Reef name & Arajipe & Coroa Alta N & Coroa Alta S & Itassepanema & Alagadas & Naufragio \\
Number reef sites & 1 & 1 & 1 & 1 & 1 & 1 \\
Coral cover \% & $3.2 \pm 1.8$ & $2.3 \pm 0.4$ & $9.4 \pm 1.4$ & $6.4 \pm 4.9$ & $3.4 \pm 3.8$ & $5.2 \pm 5.0$ \\
Corals >20cm (\#./site, $60 \mathrm{~m}^{-2}$ ) & $11.0 \pm 0.0$ & $13.0 \pm 0.0$ & $75.0 \pm 0.0$ & $22.0 \pm 0.0$ & $18.0 \pm 0.0$ & $60.0 \pm 0.0$ \\
Colony size (cm) & $34.0 \pm 14.5$ & $28.0 \pm 7.0$ & $33.5 \pm 13.5$ & $45.5 \pm 35.5$ & $44.5 \pm 47.5$ & $33.0 \pm 16.0$ \\
Number of coral species & $6.0 \pm 0.0$ & $4.0 \pm 0.0$ & $6.0 \pm 0.0$ & $7.0 \pm 0.0$ & $6.0 \pm 0.0$ & $7.0 \pm 0.0$ \\
Coral recruits (\#.m-2) & $3.0 \pm 0.0$ & $0.0 \pm 0.0$ & $2.0 \pm 0.0$ & $0.0 \pm 0.0$ & $0.0 \pm 0.0$ & $0.0 \pm 0.0$ \\
Recent death (\%) & $0.0 \pm 0.0$ & $6.0 \pm 2.0$ & $20.0 \pm 10.0$ & $0.0 \pm 0.0$ & $8.0 \pm 4.5$ & $18.5 \pm 12.5$ \\
Old mortality (\%) & $34.0 \pm 24.5$ & $9.0 \pm 5.0$ & $23.0 \pm 18.0$ & $23.0 \pm 21.0$ & $25.0 \pm 17.5$ & $16.5 \pm 13.5$ \\
Bleached colonies (\%) & $0.0 \pm 0.0$ & $0.0 \pm 0.0$ & $0.0 \pm 0.0$ & $0.0 \pm 0.0$ & $0.0 \pm 0.0$ & $0.0 \pm 0.0$ \\
Macro algae (\%) & $35.7 \pm 26.1$ & $46.4 \pm 20.6$ & $44.1 \pm 29.1$ & $27.2 \pm 25.2$ & $62.3 \pm 27.1$ & $48.3 \pm 28.2$ \\
Turf algae (\%) $(\%)$ & $30.3 \pm 28.9$ & $28.7 \pm 20.4$ & $33.2 \pm 23.5$ & $34.1 \pm 36.4$ & $18.6 \pm 21.0$ & $43.8 \pm 29.0$ \\
Coralline algae (\%) & $34.0 \pm 21.6$ & $25.0 \pm 13.8$ & $22.7 \pm 19.7$ & $35.4 \pm 29.6$ & $19.1 \pm 16.6$ & $7.9 \pm 9.7$ \\
Macro canopy height (cm) & $2.8 \pm 2.9$ & $3.7 \pm 5.4$ & $1.0 \pm 1.0$ & $2.0 \pm 2.6$ & $3.1 \pm 2.8$ & $2.6 \pm 2.0$ \\
Macroalgal index & 103.9 & 152.3 & 37.9 & 51.6 & 134.1 & 86.1
\end{tabular}

from 12.8 to 35.2 recruits $/ \mathrm{m}^{2}$, and the turf algae dominated over macro and corallines. In the offshore mushroom reefs the average coral cover reached the value of $12.3 \pm 3.6 \%$, whereas in the reefs from the coastal arc (Timbebas, Lixa and Paredes) these values ranged from $7.7 \pm 3.4 \%$ in Lixa Reef, to $12.1 \pm 4.6 \%$ in the Paredes reefs. Percentage of recent death during this survey varied from $2.5 \pm 3.2 \%$ to $20.5 \pm 29.2 \%$ in the reefs from the coastal arc, while in the fringing reefs was less than $13 \%$. The average percentage of recent death was of $18.4 \pm 9$ for the offshore mushroom reefs; while old mortality varied between $9.5 \pm 20.0 \%$ and $30.6 \pm 12.1 \%$ in most of the surveyed reefs. The percentage of bleached coral colonies was 
TABLE 5

Coral and algae condition of reefs from the Abrolhos region located $>5 \mathrm{~km}$ off the coast of the state of Bahia, in Eastern Brazil. Coral parameters measured along six $(10 \mathrm{~m}$ long) transects at each reef site, density of coral recruits and algae characteristics recorded in $30(0.25 \mathrm{~cm})$ quadrats per transect. Survey performed in 2000. Data averaged from reef sites. Mean and standard deviation

\begin{tabular}{|c|c|c|c|c|}
\hline \multirow{2}{*}{$\begin{array}{l}\text { Reef area } \\
\text { Reef name }\end{array}$} & \multicolumn{4}{|c|}{ Abrolhos } \\
\hline & St. Barbara N & St. Barbara W & St. Barbara S & Parcel Abrolhos \\
\hline Number reef sites & 3 & 2 & 3 & 5 \\
\hline Coral cover $\%$ & $8.4 \pm 2.5$ & $9.7 \pm 3.3$ & $5.9 \pm 2.2$ & $21.1 \pm 3.9$ \\
\hline Coral $>20 \mathrm{~cm}\left(\# .60 \mathrm{~m}^{-2}\right)$ & $85.3 \pm 35.9$ & $166.0 \pm 31.1$ & $44.6 \pm 12.8$ & $108.4 \pm 7.7$ \\
\hline Colony size $(\mathrm{cm})$ & $41.3 \pm 4.8$ & $41.9 \pm 6.7$ & $43.5 \pm 3.6$ & $42.3 \pm 4.8$ \\
\hline Number coral species & $4.3 \pm 2.0$ & $5.0 \pm 0.0$ & $6.6 \pm 1.1$ & $7.4 \pm 1.6$ \\
\hline Coral recruits $\left(\# \cdot \mathrm{m}^{-2}\right)$ & $16.6 \pm 11.7$ & $12.5 \pm 3.7$ & $10.3 \pm 2.7$ & $37.4 \pm 6.8$ \\
\hline Recent death (\%) & $4.5 \pm 1.3$ & $2.7 \pm 0.1$ & $4.3 \pm 5.1$ & $5.6 \pm 0.8$ \\
\hline Old mortality (\%) & $20.9 \pm 0.1$ & $24.3 \pm 10.1$ & $21.6 \pm 4.2$ & $20.5 \pm 2.0$ \\
\hline Bleached colonies $(\%)$ & $0.0 \pm 0.0$ & $2.4 \pm 0.4$ & $1.7 \pm 1.6$ & $3.4 \pm 2.1$ \\
\hline Macro algae $(\%)$ & $21.6 \pm 31.5$ & $24.7 \pm 16.1$ & $14.7 \pm 2.2$ & $3.8 \pm 2.6$ \\
\hline Turf algae $(\%)$ & $70.9 \pm 29.9$ & $67.2 \pm 16.0$ & $75.7 \pm 2.8$ & $69.5 \pm 7.2$ \\
\hline Coralline algae $(\%)$ & $7.5 \pm 2.8$ & $7.9 \pm 0.2$ & $8.9 \pm 1.3$ & $26.6 \pm 6.4$ \\
\hline Macro canopy height $(\mathrm{cm})$ & $2.1 \pm 0.2$ & $2.6 \pm 0.0$ & $3.4 \pm 0.6$ & $1.3 \pm 0.4$ \\
\hline Macroalgal index & $49.6 \pm 72.3$ & $64.2 \pm 42.3$ & $51.1 \pm 16.5$ & $5.4 \pm 3.4$ \\
\hline
\end{tabular}

less than $11 \%$ in all reefs. The number of coral recruits per square meters varied from $10.4 \pm 1.1$ individuals $/ \mathrm{m}^{2}$ to over 40 and the highest values were found in the reefs from the coastal arc. Turf algae (69\% to $90 \%)$ dominate, again, over macro and corallines (Table 6).

In 2002, live stony coral cover and the number of coral colonies still presented the lowest values in the reefs that surround the South coast of St. Barbara Island (7.0 $\pm 3.4 \%$ and 47 colonies per site), as also the coastal reefs closest to the coastline, the Lixa Reef $(6.8 \pm 2.2 \%$ and 71 colonies) and the Leste Reef $(5.6 \pm 0.4 \%$ and 11 colonies per site), when compared with most of the other investigated reef sites. Recent death higher than $20 \%$ was found only in one site (Redonda Island reef), but old mortality reached values over $12 \%$ in all surveyed reefs. The density of coral recruits lower than 10 individuals $/ \mathrm{m}^{2}$ was only found in the reef that surrounds the South shore of St. Barbara Island. Turf algae still dominate with percentages over $45 \%$ in all reefs (Table 7).

The 2005 survey comprised only three reefs in Abrolhos. Live stony coral cover was
$6.3 \pm 3.0 \%$ in the South St. Barbara Island Reef, where the number of coral colonies was also the lowest (60 corals per site) in the fringing reefs. In the other surveyed island (Siriba), coral cover reached values over $10 \%$, and the corals density was $>80$ colonies in the site. The percentage of recent death reached the value of $5 \%$ in all surveyed reefs, and old mortality was more than $20 \%$ in the fringing reefs of St. Barbara Island. Observed bleached colonies had values higher than $20 \%$. Coral recruits reached values higher than 30 individuals $/ \mathrm{m}^{2}$ in all sites. Turf algae (values from $60.0 \pm 34.8 \%$ to $83.5 \pm 17.5 \%$ ) dominated over macro and corallines (Table 8).

The assessment of the reefs from the Itacolomis Group: In the three sites of the Itacolomis reefs (Canudos, Pedra do Silva and Pedra do Cavalo) assessed in 2005, live stony coral cover ranged between $11.7 \pm 6.8 \%$ and $16.0 \pm 12.7 \%$, recent death was very low, less than $6 \%$ in all reef sites, but old mortality was over $27 \%$. Bleached coral colonies ranged from $4.7 \%$ to $16.5 \%$ and coral recruits reached 


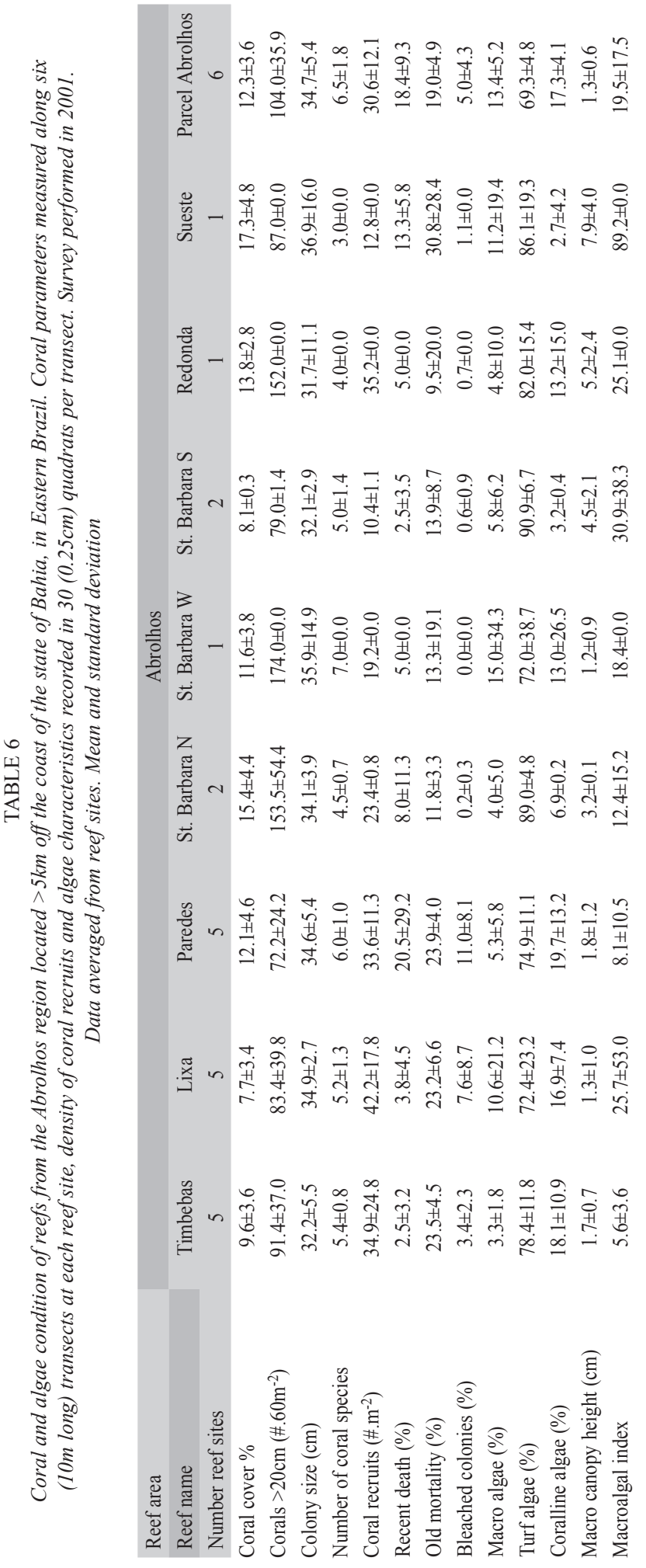




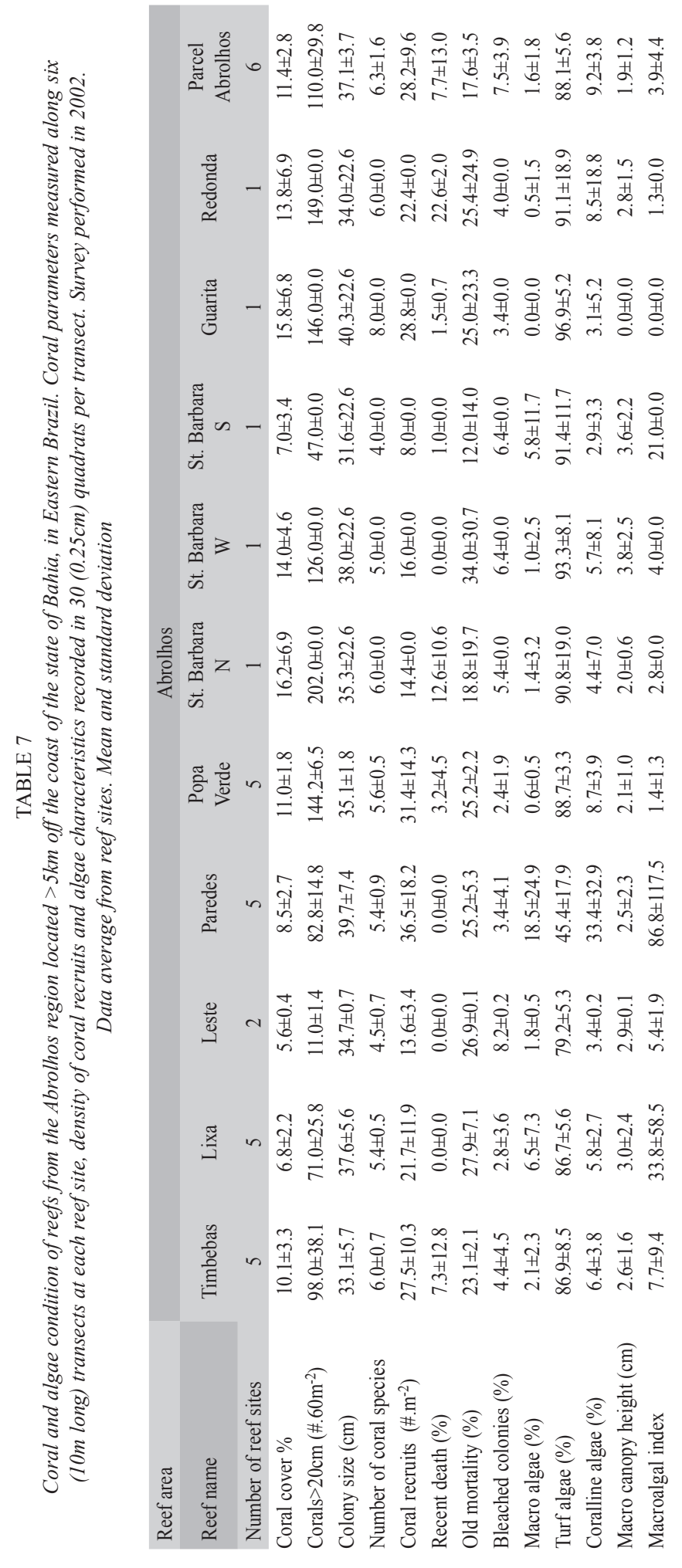


TABLE 8

Coral and algae condition of reefs from Itqcolomis reefs and the Abrolhos region, located $>5 \mathrm{~km}$ off the coast of the state of Bahia, in Eastern Brazil. Coral parameters measured along six (10mlong) transects at each reef site, density of coral recruits and algae characteristics recorded in $30(0.25 \mathrm{~cm})$ quadrats per transect. Survey performed in 2005. Mean and standard deviation

\begin{tabular}{|c|c|c|c|c|c|c|}
\hline Reef area & & Itacolomis & & & Abrolhos & \\
\hline Reef name & $\begin{array}{c}\text { Pedra do } \\
\text { Cavalo }\end{array}$ & $\begin{array}{l}\text { Pedra do } \\
\text { Silva }\end{array}$ & Canudos & $\begin{array}{c}\text { St. Barbara } \\
\text { N }\end{array}$ & $\begin{array}{c}\text { St. Barbara } \\
\text { S }\end{array}$ & Siriba \\
\hline Number reef sites & 1 & 1 & 1 & 1 & 1 & 1 \\
\hline Coral cover $\%$ & $11.7 \pm 6.8$ & $16.0 \pm 12.7$ & $15.0 \pm 12.5$ & $16.2 \pm 0.0$ & $6.3 \pm 0.0$ & $10.7 \pm 0.0$ \\
\hline Coral $>20 \mathrm{~cm}\left(\# .60 \mathrm{~m}^{-2}\right)$ & $85.0 \pm 0.0$ & $106.0 \pm 0.0$ & $89.0 \pm 0.0$ & $170.0 \pm 0.0$ & $60.0 \pm 0.0$ & $81.0 \pm 0.0$ \\
\hline Colony size (cm) & $42.7 \pm 34.8$ & $41.2 \pm 25.7$ & $35.5 \pm 24.1$ & $34.6 \pm 0.0$ & $31.9 \pm 0.0$ & $30.5 \pm 0.0$ \\
\hline Number coral species & $8.0 \pm 0.0$ & $7.0 \pm 0.0$ & $7.0 \pm 0.0$ & $6.0 \pm 0.0$ & $6.0 \pm 0.0$ & $4.0 \pm 0.0$ \\
\hline Coral recruits $\left(\# . \mathrm{m}^{-2}\right)$ & $52.3 \pm 0.0$ & $26.1 \pm 0.0$ & $36.8 \pm 0.0$ & $52.8 \pm 0.0$ & $41.6 \pm 0.0$ & $33.6 \pm 0.0$ \\
\hline Recent death (\%) & $5.0 \pm 0.0$ & $6.0 \pm 2.2$ & $0.0 \pm 0.0$ & $5.0 \pm 0.0$ & $5.0 \pm 0.0$ & $5.0 \pm 0.0$ \\
\hline Old mortality (\%) & $27.1 \pm 18.4$ & $29.0 \pm 22.0$ & $28.5 \pm 25.0$ & $23.6 \pm 22.9$ & $21.6 \pm 19.3$ & $16.1 \pm 17.5$ \\
\hline Bleached colonies $(\%)$ & $16.5 \pm 0.0$ & $4.7 \pm 0.0$ & $10.1 \pm 0.0$ & $20.6 \pm 0.0$ & $28.3 \pm 0.0$ & $24.7 \pm 0.0$ \\
\hline Macro algae (\%) & $0.0 \pm 0.0$ & $42.5 \pm 37.8$ & $10.5 \pm 22.9$ & $0.0 \pm 0.0$ & $7.4 \pm 9.3$ & $22.5 \pm 31.3$ \\
\hline Turf algae (\%) & $80.0 \pm 32.8$ & $56.7 \pm 38.7$ & $88.3 \pm 22.6$ & $83.5 \pm 17.8$ & $80.5 \pm 17.8$ & $60.0 \pm 34.8$ \\
\hline Coralline algae ( \%) & $20.0 \pm 32.8$ & $0.9 \pm 1.9$ & $1.2 \pm 3.0$ & $16.3 \pm 17.6$ & $12.1 \pm 14.0$ & $17.2 \pm 24.8$ \\
\hline Macro canopy height $(\mathrm{cm})$ & $0.0 \pm 0.0$ & $3.9 \pm 2.6$ & $2.6 \pm 0.7$ & $0.0 \pm 0.0$ & $2.0 \pm 1.6$ & $5.3 \pm 2.6$ \\
\hline Macroalgal index & 0.0 & 167.3 & 27.7 & $0.0 \pm 0.0$ & $14.9 \pm 0.0$ & $1.2 \pm 0.0$ \\
\hline
\end{tabular}

values that ranged from 26.1 to 52.3 individuals $/ \mathrm{m}^{2}$. Turf algae were dominant $(56.7 \pm 38.7 \%$ to $88.3 \pm 22.6 \%$ ) over macro and corallines (Table 8).

Spatial patterns: The spatial patterns in the reef vitality indices is clearly depicted based on four parameters of the coral community: percent of living coral cover, number of colonies $>20 \mathrm{~cm}$ per site, number of coral species and density of coral recruits (Fig. 3). The ordination plot (MDS) reproduces the reef geographic distribution quite well, from the North Coast (NC) down to Abrolhos reefs, in the Southernmost part of the region in focus, with a low stress (0.05). Four groups of reefs are recognized: 1. Northern Coast reefs, 2. Tinharé/Boipeba islands reefs grouped with Cabralia reefs, 3. Itacolomis reefs, and 4. Abrolhos reefs.

When the indices of bleaching, coral mortality (recent and old) and algae (macroalgal index and turf algae cover) were included, the NC reefs were excluded from the analysis because these indices were not measured there. The MDS ordination (stress 0.12 ) depicts very well the distinction between nearshore reefs (Tinharé/Boipeba/Camamu and Cabrália/Porto Seguro regions) and offshore reefs (Itacolomis and Abrolhos reefs) (Fig. 4). This tendency occurs mainly due to a high algal cover and biomass (macroalgae and turf algae), to a low number of colonies and to a lower density of coral recruits, which is, may be, a sign of reef degradation in these sites.

The ANOSIM test, considering the proximity to shore as the test factor, results in a global $\mathrm{R}$ of 0.932 . In a set of 999 permutations, no sample value was greater than or equal to the global R, which means that the dissimilarity of nearshore (from TBC to CPS reefs) and offshore (Abrolhos coastal and outer arcs reefs) reefs is significant in terms of the indices used at a significance level of $0.1 \%$. The similarity degree among stations within each group (nearshore and offshore reefs) and dissimilarity between the reefs groups indicates that the grouping is consistent (Table 9). Similarity 

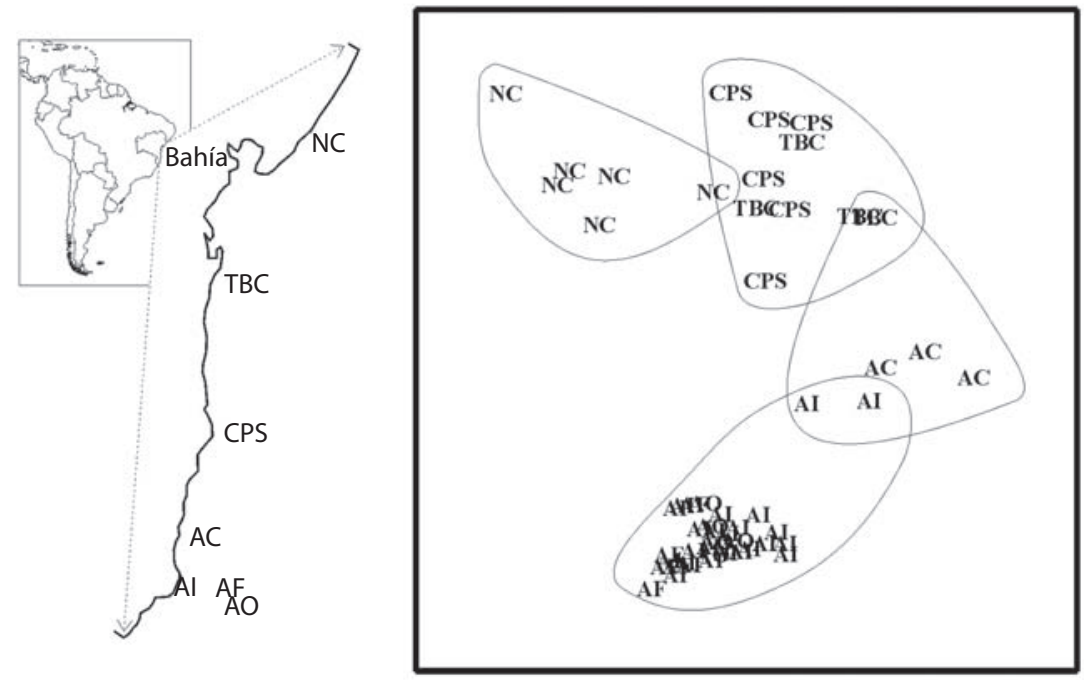

Fig. 3. MDS plot of all surveyed reef sites. $\mathrm{NC}=$ North Coast; $\mathrm{TB}=$ Tinharé and Boipeba islands; $\mathrm{CPS}=\mathrm{Cabrália} ; \mathrm{AC}=$ Itacolomis; $\mathrm{AI}=$ Abrolhos inner (coastal) arc; $\mathrm{AF}=$ Abrolhos fringing reefs; $\mathrm{AO}=$ Abrolhos offshore mushroom reefs. Only coral related indices were used (percent of living coral cover, number of colonies $>20 \mathrm{~cm}$ per square meter, number of coral species per reef site and density (No. indiv. $/ \mathrm{m}^{2}$ ) of coral recruits).

\section{Nearshore X Offshore reefs}

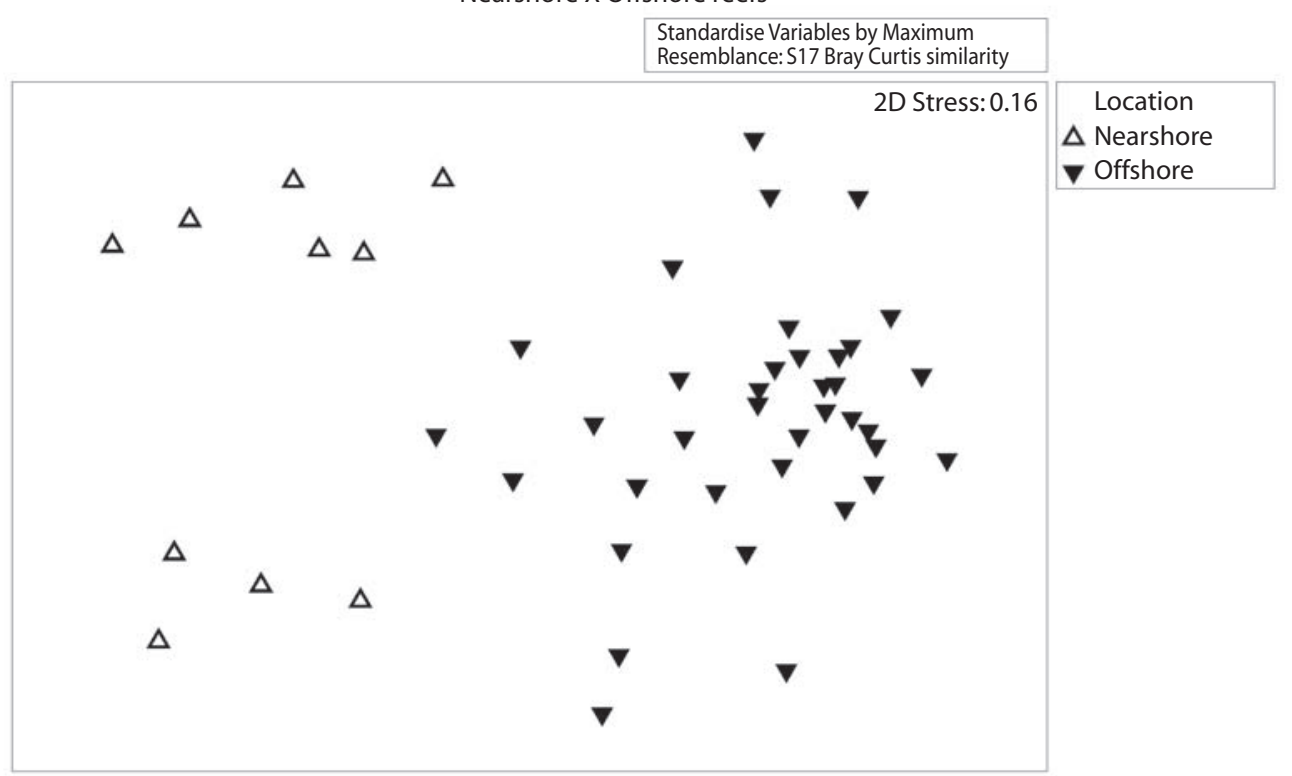

Fig. 4. MDS plot of sites surveyed south of Salvador City. $\mathrm{TBC}=$ Tinharé and Boipeba islands; $\mathrm{CPS}=\mathrm{Cabrália}$; $\mathrm{C}=$ Itacolomis; I= Abrolhos inner (coastal) arc; $\mathrm{F}=$ Abrolhos fringing reefs; $\mathrm{O}=$ offshore mushroom reefs. Sites gather into two groups: nearshore (upper part of graph) and offshore (lower part of graph). All indices used. 
TABLE 9

Results of Similarity Percentages (SIMPER) test. Similarity within each group of reefs, nearshore and offshore, are high, as well as dissimilarity between the two groups

\begin{tabular}{|c|c|c|c|c|c|c|}
\hline \multicolumn{7}{|c|}{ SIMILARITY WITHIN GROUPS OF REEFS (Nearshore X Offshore reefs) } \\
\hline & AV. VALUE & \multirow{2}{*}{\multicolumn{2}{|c|}{ AVERAGE }} & RATIO & CONTRIB $\%$ & CUM $\%$ \\
\hline Nearshore reefs & Av. Similarity $=71.7$ & & & & & \\
\hline Macroalgae index & 78.7 & \multicolumn{2}{|c|}{31.6} & 3.27 & 44.11 & 44.11 \\
\hline Turf algae $(\%)$ & 34.2 & \multicolumn{2}{|c|}{17.5} & 3.40 & 24.34 & 68.45 \\
\hline Old mortality (\%) & 17.4 & \multirow{2}{*}{\multicolumn{2}{|c|}{7.4}} & 2.63 & 10.35 & 78.79 \\
\hline Offshore reefs & Av. Similarity $=71.19$ & & & & & \\
\hline Turf algae $(\%)$ & 81.1 & \multicolumn{2}{|c|}{25.3} & 3.09 & 35.51 & 35.51 \\
\hline No. coral colonies & 93.3 & \multicolumn{2}{|c|}{21.3} & 1.76 & 29.98 & 65.49 \\
\hline Old mortality (\%) & 28.6 & \multicolumn{2}{|c|}{7.0} & 3.14 & 9.89 & 75.39 \\
\hline Coral recruits (No. Ind. $/ \mathrm{m}^{2}$ ) & 26.8 & \multicolumn{2}{|c|}{6.6} & 2.06 & 9.24 & 84.63 \\
\hline \multicolumn{7}{|c|}{ AVERAGE DISSIMILARITY BETWEEN GROUPS = 60.62} \\
\hline & Offshore & Nearshore & & & & \\
\hline SPECIES & AV. ABUND. & AV. ABUND. & AV. DISS. & RATIO & CONTRIB $\%$ & CUM $\%$ \\
\hline No. coral colonies & 93.3 & 2.5 & 18.87 & 2.07 & 31.13 & 31.13 \\
\hline Macroalgal index & 26.9 & 78.7 & 16.11 & 1.95 & 26.57 & 57.70 \\
\hline Percent turf algae & 81.1 & 34.2 & 10.41 & 2.73 & 17.18 & 74.87 \\
\hline Coral recruits (No. Ind. $/ \mathrm{m}^{2}$ ) & 26.8 & 1.76 & 5.45 & 1.74 & 8.99 & 83.86 \\
\hline
\end{tabular}

among nearshore reefs is assured mainly by macroalgal index, percentage of turf algae and of old mortality (Table 9); while in the offshore reefs, by turf algae cover, number of coral colonies, old mortality percent and the density of coral recruits. The density of coral colonies, macroalgal index, percent of turf algae and density of coral recruits are responsible of the average dissimilarity between these two groups (Table 9). The analysis of similarity (ANOSIM) between the reefs from the coastal and the outer arcs in Abrolhos region indicated no difference (significance level of 97.8\%).

Temporal patterns: The question addressed here is if there are temporal trends in the coral health indices variation in the Abrolhos reefs. In this approach, assessments made in 2000, 2001, 2002 and 2005 in the Abrolhos region were used.

For the evaluation of differences between years of survey, the first null hypothesis of the ANOSIM test, in its two-way nested layout, is that there is no difference among the reefs. The Global $\mathrm{R}$ is equal to 0.333 , and the significance level of the statistic is $0.1 \%$ (no permuted statistic is greater than the Global R). The relatively low rate $(R)$ value, indicates that the differences between sites of the various reefs are not much greater than differences among sites of the same reef. Thus, separate MDS plots were made for each reef, so that the spatial pattern of the set of indices could be analyses. MDS ordination of the coastal arc reefs has a relatively high stress $(0.10)$ and shows that the condition of Pedra de Leste reef in 2002 (E2) was different from the remaining stations (Fig. 5A). Separate plots of three reefs, Timbebas, Lixa and Paredes, were drawn (Fig. 5 B, C and D), as well, to check for differences within each group of reefs, but none seems to depict changes from 2001 to 2002. What appears in these plots, which have low stresses, is that one or two stations in each reef are less similar to the bulk of stations. This must be the reason for the low value of Global R of the ANOSIM test. We, then, proceeded to the testing of the second null hypothesis that there is no difference among the three years of survey. The test resulted in a Global $\mathrm{R}$ with negative value close 
$A=$ Coastal Arc reefs, Stress $=0.10$

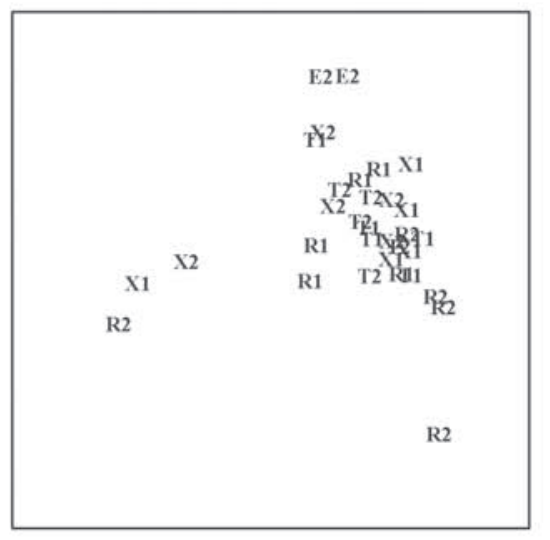

$C=$ Lixa reefs, Stress $=0.04$

2

1

122

$1_{1}^{2}$

$\mathrm{E}=$ Abrolhos Archipielago, Stress $=0.09$

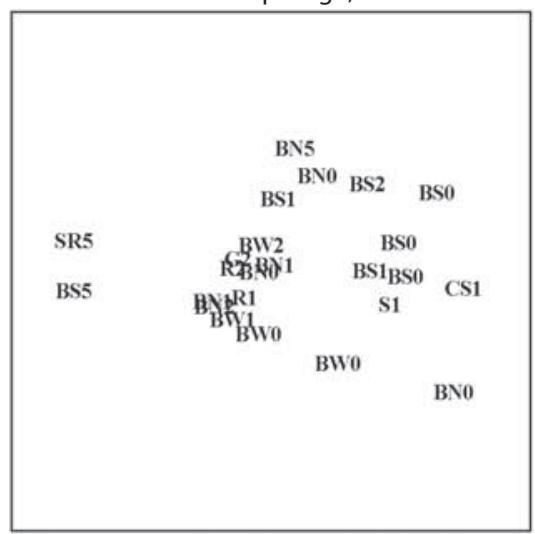

$B=$ Timbebas reefs, Stress $=0.02$

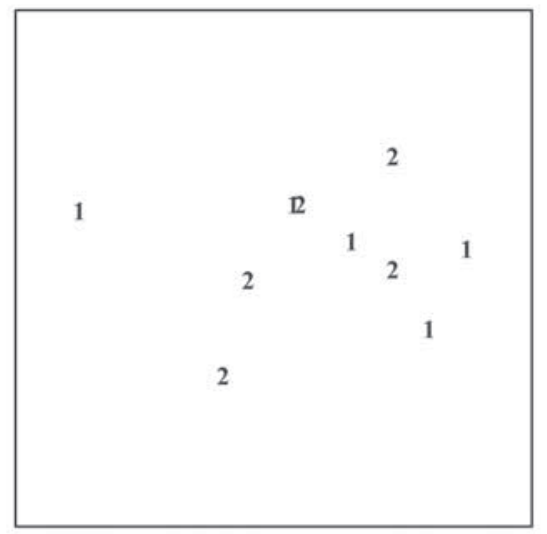

$D=$ Paredes reefs, Stress $=0.01$

$\frac{2}{2}$

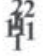

Fig. 5. MDS plots of Abrolhos reefs surveys of 2000 (0), 2001 (1), 2002 (2). In Abrolhos Archipelago there is a survey in 2005 (5). $\mathrm{A}=$ all sites; $\mathrm{B}=$ Timbebas reefs; $\mathrm{C}=$ Lixa reefs; $\mathrm{D}=$ Paredes reefs; $\mathrm{E}=$ Abrolhos Archipelago; $\mathrm{F}=$ offshore mushroom reefs. Where multiple sites are compared (5A and 5E) labels comprise a prefix letter denoting the site and a suffix digit denoting the year of the survey. In Abrolhos Archipelago the number that follows the acronym refers to the year of the survey; BS= Southern side of Santa Barbara Island; BW= Western side of Santa Barbara Island; BN= Northern side of Santa Barbara Island; $\mathrm{R}=$ Redonda Island; $\mathrm{G}=$ Guarita Island; $\mathrm{SR}=$ Siriba Island; $\mathrm{S}=$ Sueste Island; $\mathrm{CS}=$ mushroom reef near Siriba Island. Southern sites of SB Island tend to group together, independently of the year of survey. 
to zero (-0.123) and a significance level of $85 \%$, what indicates that no difference among years occurred.

Vital conditions of the reefs in the more offshore areas seem to be quite stable, both in the Archipelago plot (Fig. 5E) and in the offshore mushroom reefs plot (Fig. 5F). However, the assessment made in 2005 in the archipelago revealed a higher percentage of bleached coral colonies and higher recruits density (Table 8). An ANOSIM test for this group of reefs did not show a significant change in the overall vitality of the reefs, though, as shown by a Global R of 0.176 , and a significance level of $2.9 \%$.

The plot of the offshore mushroom reefs stations (Fig. 5F) depicts three stations very distinct from the others, but with no relation to assessment events (years). However, an interesting situation appears. Despite the aggregation of most stations and assessments, there is a subtle tendency to separate 2001 and 2002 assessments to opposite sides, while the first assessment (2000) remains in between (Fig. 5F).

Brazilian East Coast reefs in the Atlantic context: A comparison of data from the reefs of East Coast of Brazil (SouthwestSW-Atlantic) with data means from AGRRA surveys in the Northwest (NW) Atlantic reefs (Kramer 2003) is presented in Table 10. It gives the mean sample effort for the 26 assessed reefs in Bahia for comparison with mean data from 19 assessments accomplished in shallow $(\leq 5 \mathrm{~m})$ and deep $(>5 \mathrm{~m})$ reefs of the Northwest Atlantic Ocean (including the Bahamas, Gulf of Mexico, Western Caribbean, Central Caribbean, Eastern Caribbean and Southern Caribbean). Most of the reefs in SW Atlantic are classified as shallow reefs, and the fewer ones identified in the class of deep reefs have depths less than $10 \mathrm{~m}$, that is the average depth of the NW Atlantic reefs. The MDS plot (stress of 0.22, Fig. 6) made with the mean value for each indicator of

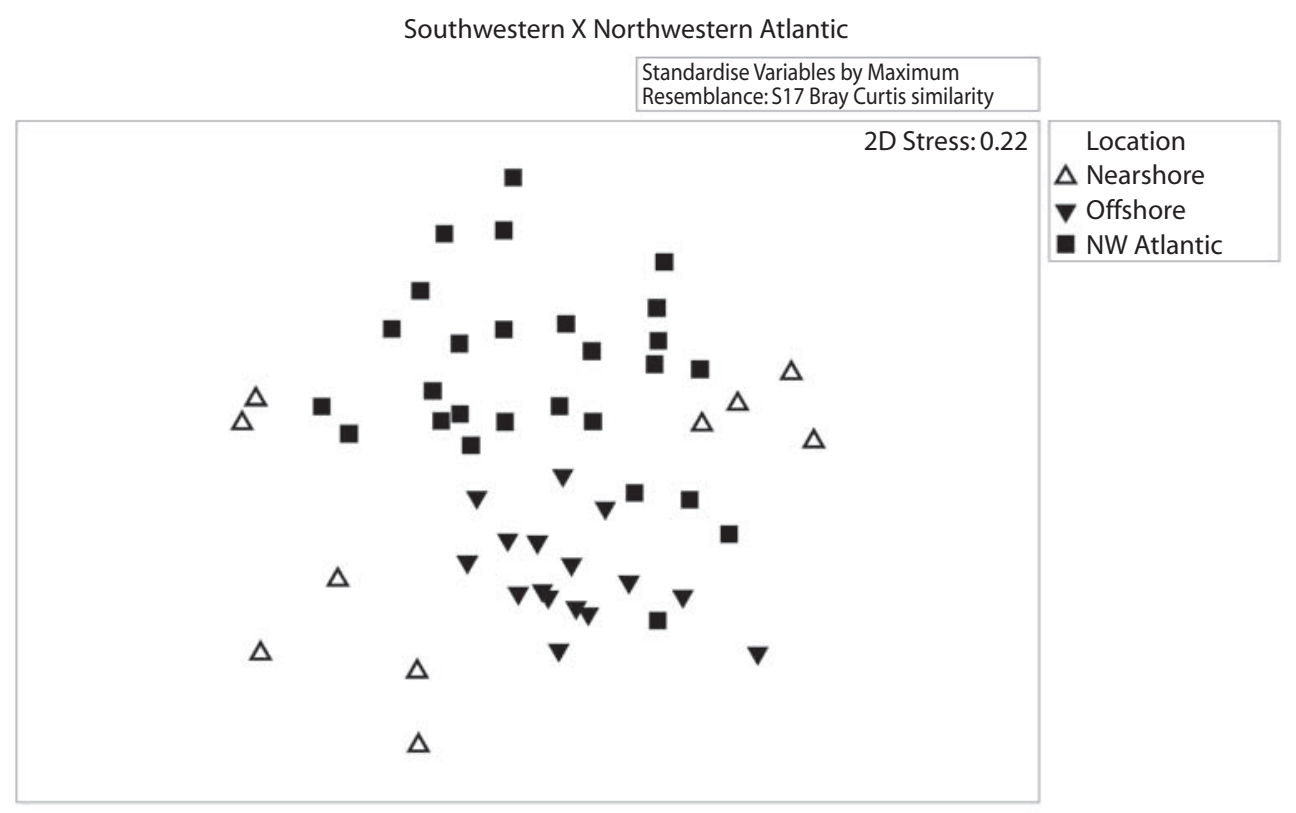

Fig. 6. MDS plot of East coast of Brazil (Southwest Atlantic) reefs, grouped as nearshore reefs (black triangles), offshore reefs (inverted black triangles) and North Atlantic reefs (grey squares). North Atlantic reefs data obtained from Kramer (2003). Indices used are, live coral cover, coral recruit density, and, percentages of recent death, old mortality and bleached colonies. 
TABLE 10

Summary of means of selected coral indicators from AGRRA in Brazil, compared with means of 19 AGRRA surveys in the North Atlantic Ocean (Kramer 2003), in shallow ( $<\underline{5}$ m depth) and deep ( $>5 \mathrm{~m}$ depth) reef sites. Nearshore $=$ reefs located less than $5 \mathrm{~km}$ off the coast, Offshore $=$ reefs located more than $5 \mathrm{~km}$ off the coast. Coral recruits $=$ colonies $<2 \mathrm{~cm}$ diameter, $n=$ number of reef sites. Mean and standard deviation

\begin{tabular}{|c|c|c|c|c|c|c|c|c|}
\hline & & & 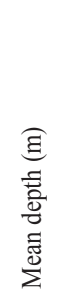 & 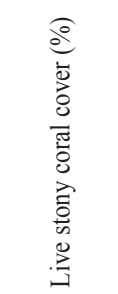 & 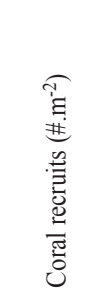 & 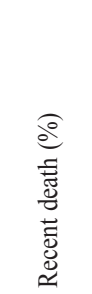 & 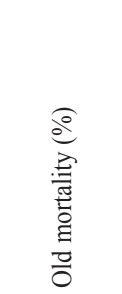 & 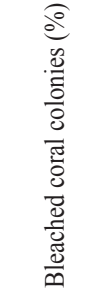 \\
\hline & $\begin{array}{l}\text { REEF } \\
\text { AREAS }\end{array}$ & SHALLOW REEFS ( $\leq 5 \mathrm{~m}$ depth) & & & & & & \\
\hline \multirow[t]{9}{*}{ Nearshore reefs } & Tinharé/ & Praia do Quadro $n=1$ & 3.6 & 2.7 & 5.0 & 5.0 & 13.0 & 12.0 \\
\hline & Boipeba & Garapua $\mathrm{n}=1$ & 3.9 & 5.3 & 5.0 & 5.0 & 11.0 & 19.0 \\
\hline & & Moreré $n=1$ & 4.0 & 2.8 & 2.0 & 5.0 & 10.0 & 23.0 \\
\hline & & Bainema $n=1$ & 3.9 & 2.0 & 2.0 & 10.0 & 10.0 & 23.0 \\
\hline & Cabralia & Coroa Alta Norte $n=1$ & 5.0 & 2.3 & 0 & 6.0 & 9.0 & 0 \\
\hline & & Coroa Alta Sul n=1 & 5.0 & 9.4 & 2.0 & 20.0 & 23.0 & 0 \\
\hline & & Itassepanema $\mathrm{n}=1$ & 4.8 & 6.4 & 0 & 0 & 23.0 & 0 \\
\hline & & Alagadas $n=1$ & 4.9 & 3.4 & 0 & 8.0 & 25.0 & 0 \\
\hline & & Naufrágio $n=1$ & 4.8 & 5.2 & 0 & 18.5 & 16.5 & 0 \\
\hline \multirow[t]{15}{*}{ Offshore reefs } & Itacolomis & Canudos $n=1$ & 3.5 & 15.0 & 36.8 & 0 & 28.5 & 10.1 \\
\hline & & Pedra do Silva $n=1$ & 2.5 & 16.0 & 26.1 & 6.0 & 29.0 & 4.7 \\
\hline & & Pedra do Cavalo $n=1$ & 2.0 & 11.7 & 52.3 & 5.0 & 27.1 & 16.5 \\
\hline & Abrolhos & Lixa $n=11$ & 4.1 & 7.7 & 32.0 & 3.8 & 23.2 & 5.2 \\
\hline & & Leste $n=2$ & 1.8 & 5.6 & 13.6 & 0 & 26.9 & 8.2 \\
\hline & & Paredes $n=10$ & 4.2 & 10.3 & 35.0 & 10.3 & 24.6 & 7.2 \\
\hline & & Timbebas $n=11$ & 4.8 & 10.0 & 32.2 & 4.9 & 23.3 & 3.9 \\
\hline & & S St. Barbara Is. $n=8$ & 4.6 & 6.8 & 17.6 & 3.2 & 17.3 & 9.3 \\
\hline & & W St. Barbara Is. $\mathrm{n}=6$ & 4.0 & 11.8 & 15.9 & 2.6 & 24.0 & 2.9 \\
\hline & & N St. Barbara Is. $\mathrm{n}=7$ & 4.0 & 14.0 & 26.8 & 7.5 & 18.8 & 6.6 \\
\hline & & Redonda Is. $\mathrm{n}=1$ & 3.5 & 13.8 & 28.8 & 13.8 & 17.5 & 2.4 \\
\hline & & Guarita Is. $\mathrm{n}=1$ & 4.5 & 15.8 & 28.8 & 1.5 & 25.0 & 3.4 \\
\hline & & Mean & 4.0 & 8.5 & 17.2 & 6.5 & 20.3 & 7.5 \\
\hline & & Mean of North Atlantic reef sites & 3.2 & $18.4 \pm 9.2$ & $2.6 \pm 1.4$ & $4.8 \pm 7.5$ & $26.6 \pm 11.3$ & $7.1 \pm 8.4$ \\
\hline & & DEEP REEFS $(>5 \mathrm{~m})$ & & & & & & \\
\hline Nearshore reef & Cabralia & Arajipe $n=1$ & 6.8 & 3.2 & 3.0 & 0 & 34.0 & 0 \\
\hline \multirow[t]{6}{*}{ Offshore reefs } & Abrolhos & Popa Verde $n=5$ & 6.8 & 11.0 & 31.4 & 3.2 & 25.2 & 2.4 \\
\hline & & Sueste Is. $\mathrm{n}=1$ & 8.0 & 17.3 & 12.8 & 13.3 & 30.8 & 1.1 \\
\hline & & Siriba Is. $n=1$ & 6.5 & 10.7 & 33.6 & 33.6 & 16.1 & 24.7 \\
\hline & & Parcel Abrolhos $n=18$ & 7.3 & 14.5 & 31.7 & 10.6 & 19.0 & 5.3 \\
\hline & & Mean & 7.0 & 11.3 & 22.5 & 12.1 & 25.0 & 6.7 \\
\hline & & Mean of North Atlantic reef sites & 10.6 & $26.1 \pm 13.2$ & $7.5 \pm 13.5$ & $4.3 \pm 4.9$ & $21.6 \pm 6.7$ & $10.3 \pm 8.7$ \\
\hline
\end{tabular}


every reef surveyed shows a clear distinction in the distribution pattern of these reefs. The points that represent Nearshore and Offshore reefs presently studied appear separated from each other, and are also apart from the NW Atlantic reefs. The ANOSIM test result shows that there are significant differences amongst the SW Atlantic nearshore and offshore groups, and between these and NW Atlantic group ( $\mathrm{R}=0.513$; no permutation above this value; $\mathrm{p}=0.1 \%$ ). SIMPER test results are shown in (Table 11). Coral recruits density distinguished Southern from Northern reefs: offshore reefs have higher number of recruits and nearshore lower number, compared to the NW Atlantic reefs (Tables 10 and 11). Live coral cover percent is lower in the SW Atlantic compared with the NW Atlantic reefs. On the other hand, bleaching was less conspicuous in the Southern reefs than in the NW Atlantic, but recent death

TABLE 11

Results of Similarity Percentages (SIMPER) test. Similarity within each group of reefs, Nearshore, Offshore and North Atlantic reefs, are high, as well as dissimilarity between the three groups

\begin{tabular}{|c|c|c|c|c|c|c|}
\hline \multicolumn{7}{|c|}{ SIMILARITY WITHIN GROUPS OF REEFS (Nearshore X Offshore X North Atlantic) } \\
\hline & AV. VALUE & \multirow{2}{*}{\multicolumn{2}{|c|}{ AVERAGE }} & RATIO & CONTRIB \% & CUM \% \\
\hline Nearshore reefs & Av. Similarity $=49.10$ & & & & & \\
\hline Old mortality $(\%)$ & 1.47 & \multicolumn{2}{|c|}{18.40} & 1.64 & 37.47 & 37.47 \\
\hline Recent death $(\%)$ & 2.44 & \multicolumn{2}{|c|}{17.30} & 1.07 & 35.24 & 72.71 \\
\hline Bleached colonies $(\%)$ & 1.77 & \multicolumn{2}{|c|}{5.93} & 0.38 & 12.07 & 84.78 \\
\hline Live coral cover $(\%)$ & 0.50 & \multicolumn{2}{|c|}{5.78} & 2.25 & 11.78 & 96.56 \\
\hline Offshore reefs & Av. Similarity $=73.22$ & & & & & \\
\hline Coral recruits (\#.m²) & 4.53 & \multicolumn{2}{|c|}{30.92} & 3.45 & 42.23 & 42.23 \\
\hline Old mortality (\%) & 1.99 & \multicolumn{2}{|c|}{15.70} & 3.36 & 21.45 & 63.67 \\
\hline Live coral cover $(\%)$ & 1.39 & \multicolumn{2}{|c|}{9.99} & 3.28 & 13.65 & 77.32 \\
\hline Recent death (\%) & 2.34 & \multicolumn{2}{|c|}{8.69} & 1.20 & 11.87 & 89.20 \\
\hline North Atlantic reefs & Av. Similarity $=60.13$ & & & & & \\
\hline Live coral cover $(\%)$ & 2.70 & \multicolumn{2}{|c|}{21.67} & 1.94 & 36.03 & 36.03 \\
\hline Old mortality (\%) & 1.98 & \multicolumn{2}{|c|}{17.90} & 2.42 & 29.76 & 65.80 \\
\hline Bleached colonies $(\%)$ & 2.08 & \multicolumn{2}{|c|}{9.65} & 1.00 & 16.04 & 81.84 \\
\hline Recent death (\%) & 1.41 & \multicolumn{2}{|c|}{6.35} & 1.18 & 10.57 & 92.40 \\
\hline \multicolumn{7}{|c|}{ DISSIMILARITY BETWEEN GROUPS OF REEFS (pairwise tests) } \\
\hline Av. Diss. $=57.08$ & Nearshore & Offshore & & & & \\
\hline PARAMETERS & AV. ABUND. & AV. ABUND. & AV. DISS. & RATIO & CONTRIB $\%$ & CUM \% \\
\hline Coral recruits $\left(\# . \mathrm{m}^{-2}\right)$ & 0.30 & 4.53 & 23.42 & 2.92 & 41.03 & 41.03 \\
\hline Recent death $(\%)$ & 2.44 & 2.34 & 12.27 & 1.27 & 21.49 & 65.51 \\
\hline Bleached colonies $(\%)$ & 1.77 & 1.63 & 11.66 & 1.67 & 20.43 & 82.94 \\
\hline Live coral cover $(\%)$ & 0.50 & 1.39 & 5.19 & 1.87 & 9.09 & 92.04 \\
\hline Av. Diss. $=55.01$ & Nearshore & North Atlantic & & & & \\
\hline Bleached colonies $(\%)$ & 1.77 & 2.08 & 15.61 & 1.35 & 27.83 & 27.83 \\
\hline Live coral cover $(\%)$ & 0.50 & 2.70 & 14.93 & 1.53 & 27.15 & 54.97 \\
\hline Recent death (\%) & 2.44 & 1.41 & 14.14 & 1.21 & 24.70 & 80.68 \\
\hline Old mortality (\%) & 1.47 & 1.98 & 6.34 & 1.22 & 11.52 & 92.20 \\
\hline Av. Diss. $=48.13$ & Offshore & North Atlantic & & & & \\
\hline Coral recruits $\left(\# \cdot \mathrm{m}^{-2}\right)$ & 4.53 & 0.91 & 19.52 & 2.66 & 40.55 & 40.55 \\
\hline Recent death (\%) & 2.34 & 1.41 & 9.55 & 1.10 & 19.83 & 60.39 \\
\hline Bleached colonies $(\%)$ & 1.63 & 2.08 & 8.24 & 1.23 & 17.11 & 77.50 \\
\hline Live coral cover $(\%)$ & 1.39 & 2.70 & 7.47 & 1.16 & 15.51 & 93.01 \\
\hline
\end{tabular}


is higher in the Southern reefs, especially in nearshore sites. No causal relation between these two indices should be done, though.

\section{DISCUSSION}

The assessment of the coral reefs along the coast of the state of Bahia: Taken into account several indices of the reef vitality, from the North Coast to Abrolhos-live coral cover, number of coral colonies $>20 \mathrm{~cm}$ per square meter, density of coral recruits (number of recruits per square meter), percent of bleached coral colonies and of partial recent and old mortalities of coral surface, the macroalgal index and percentage of turf algae-, the MDS ordination depicted four major reef groups (see Figs. 3 and 4), which are mostly composed by: 1. the reefs from the North Coast area, 2. the reefs from Tinharé/Boipeba and Cabrália areas, 3. the Itacolomis reefs area, and 4. the Abrolhos reefs. The reefs from groups 1 and 2 , which are located attached to the coastline and/or less than $5 \mathrm{~km}$ from the coast, have the lowest values for the reef vitality indicators in comparison with the reefs of groups 3 (Itacolomis) and 4 (Abrolhos), which are located more than $5 \mathrm{~km}$ off the coastline.

Figure 6 illustrates the data from four indices of the reef condition, which reinforces the differences between the nearshore and offshore reefs. Live stony coral cover averages $3.6 \pm 2.4 \%$ in the nearshore reefs (North Coast, Tinharé/Boipeba and Cabralia), whereas in the Itacolomis and Abrolhos reefs, the correspondent cover estimates averages $11.6 \pm 3.5 \%$, with the reefs from the coastal arc and the fringing reef of South St. Barbara Island presenting the lowest value of this area.

The number of coral colonies $>20 \mathrm{~cm}$ diameter per square meter, shows similar results: the reefs closer to the coast present an average density of coral colonies of $22.0 \pm 22.4$ colonies per site, whereas the reefs located off the coast have an average of $102.6 \pm 42.7$ corals per site. Mean estimates of the number of coral recruits per square meter exhibit similar patterns to those above described reefs. The nearshore reefs have an average of $1.6 \pm 1.8$ recruits $/ \mathrm{m}^{2}$, whereas the majority of the surveyed reefs of Itacolomis and Abrolhos have an average of over 20 recruits $/ \mathrm{m}^{2}$.

The algal populations also contributed to differentiate the nearshore and offshore reefs. In the North Coast, Tinharé/Boipeba and Cabralia reefs, (reef sites that belong to neashore reef group of figure 4), the macroalgae index (\% macroalgae $\mathrm{x}$ macroalgae height) varies among them, with an average of $78.7 \pm 40.6$ for the nearshore reefs and of $25.9 \pm 46.9$ for the offshore reefs (Fig. 7). Comparing the relative abundance of macroalgae with the coral density, an inverse relation among them, from which nearshore and offshore reefs can be clearly distinguished.

Partial mortality does not contribute to the dissimilarity between nearshore and offshore reefs (Table 9). The percentage of recent partial mortality $(\sim<1$ year death with loss of tissue but calices still visible) of the surveyed coral colonies, have a wide variation. It ranges from zero to little over $20 \%$ across the 24 surveyed reefs (the reefs from the North Coast were excluded because of lack of data), and does not characterize any of the reef groups. The old partial mortality ( $\sim 1$ year death) varies from 9 to $35 \%$ and contributes to the similarity within nearshore and offshore reefs groups, with mean values of 17.4 and 28.6 percent of coral surface (Table 9). However, it does not contribute to the dissimilarity between nearshore and offshore reefs. Coral partial mortality can be the result of bioerosion, sedimentation, bleaching, competition and abiotic perturbations (Meesters et al. 1996). Except for diseases that have not been reported, before and during our surveys in Brazil reefs, any of the other cited stressors could have caused mortality in the surveyed reefs. Mass mortality due to bleaching has not occurred in Bahia reefs, suggesting that these may be resistant to this stressor or may be because sea surface temperature anomalies are not strong enough along the coast of Bahia.

Previous works about the Bahia coral reefs showed that dwelling communities on the top of shallow reefs located closer to the coast, are 

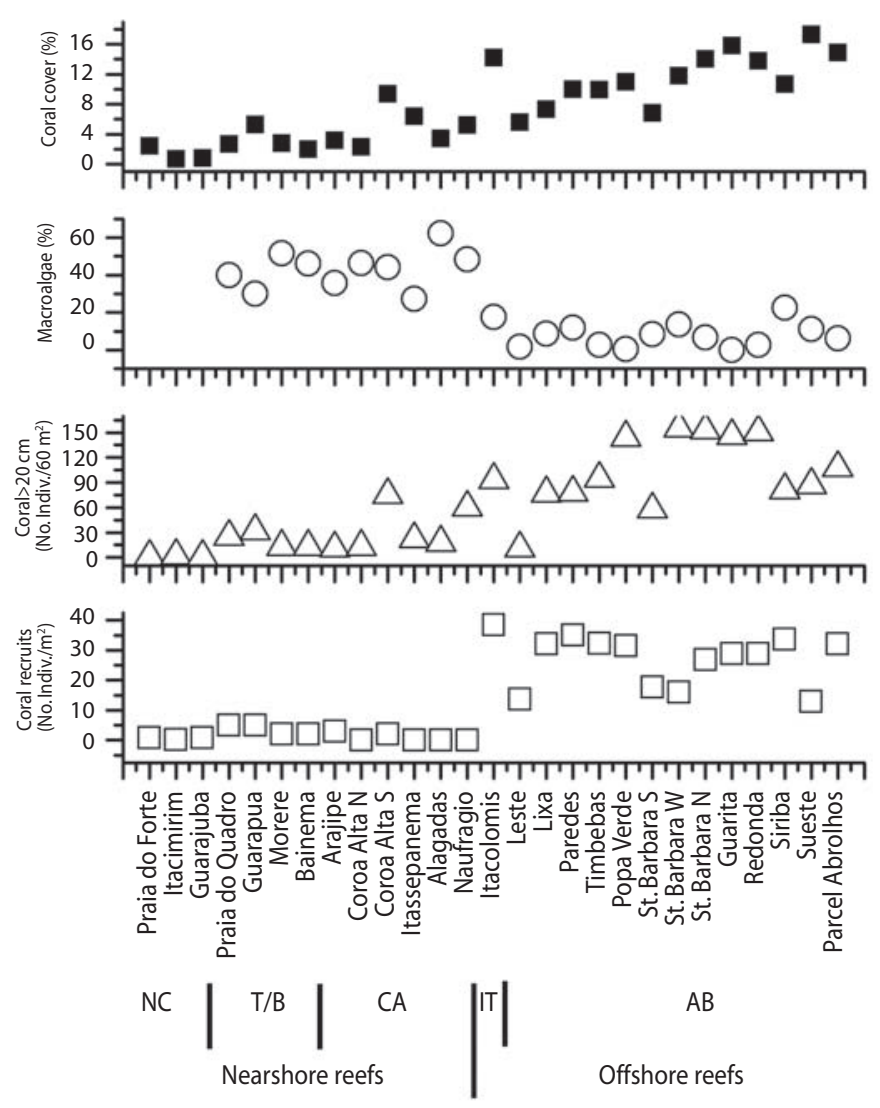

Fig. 7. Four indicators of the reef vitality depicting the major differences between the nearshore (reefs located $\leq 5 \mathrm{~km}$ off the coast) and offshore (reefs located $>5 \mathrm{~km}$ off the coast) reefs from Eastern Brazil. $\mathrm{NC}=$ North Coast; $\mathrm{T} / \mathrm{B}=\mathrm{Tinhare}$ and Boipeba islands; $\mathrm{CA}=$ Cabrália reefs, $\mathrm{IT}=$ Itacolomis reefs; $\mathrm{ABR}=$ Abrolhos reefs. Coral recruits $=$ colonies $\leq 2 \mathrm{~cm}$ diameter.

experiencing a stress resulting, chiefly, from: strong solar radiation exposition and variation of sea surface temperature; the effects of increasing sedimentation influx (Dutra et al. 2006); an abnormal increase of nutrients in the coastal waters (Costa Jr et al. 2000, Costa $\mathrm{Jr} 2001$ ); and, an elevated rate of bioerosion (Santa-Isabel et al. 2000, Reis \& Leão 2003). Those inhospitable conditions appear to be clearly deleterious to the reef-building corals in the nearshore reefs. In the offshore reefs of Abrolhos, some reefs from the inner arc (for example the Leste Reef) as well as the fringing reefs that border the South shore of St. Barbara Island and the reefs of Siriba Island, show the lowest values for the selected coral indicators.
The South St. Barbara reef is the preferred site by tourists for diving and snorkeling (Spanó et al. 2008), but the condition of the reef from the Siriba Island need to be further investigated considering that it is a site closed to visitors. The Fig. 4 shows that some of these reefs fall closer to the nearshore reefs, mainly due to a high macroalgal cover and biomass, and to a lower density of coral colonies $>20 \mathrm{~cm}$.

Thus the set of parameters assessed showed that there is a clear distinction between nearshore and offshore reefs, and that some sites from the latter group have already decayed to conditions similar to nearshore reefs (Figs. 4 and 7). These sites must be closely monitored and need to be target of management actions. 
The coral and millepore diversity of the Bahia coral reefs is not impoverished yet, considering that out of the 17 species of corals and three of millepores that were so far identified for the reefs of Abrolhos (see Table 1), 15 species of corals and three of millepores were found during measurements accomplished along $1 \mathrm{~m}$ wide band transects $(10 \mathrm{~m}$ long) in these reefs, excluding only the small corals Astrangia braziliensis and Phyllangia americana (Table 12).

Six years monitoring reefs of Abrolhos area: Reefs vital conditions have not changed significantly throughout the years of monitoring in the whole area of Abrolhos. It is evident that, despite the natural heterogeneity of the ecosystem, the numbers collected in some sites represent lowest vital conditions and show that these sites need to be managed in order to stop their degradation, as could be seen in Leste, Lixa, Paredes and South St. Barbara reefs, and some offshore mushroom reefs of Parcel dos Abrolhos (Figs. 5 and 7). Lixa and Paredes reefs are sites where fishing and tourism are frequent, thus these results are important alerts to entrepreneurs and environmental management authorities. Leste, in the whole Abrolhos area, is the closest reef to the shoreline and has been impacted by coastal processes. The sites in Abrolhos Archipelago with the lowest vital indices are those where tourism are more intense. Previous analysis on 2000 surveys (Kikuchi et al. 2003a) and 2002 (Spanó et al. 2008) had already shown this. The offshore reefs data display a difference on surveys from 2000 to 2002; however, this difference might rather be the result of inter-annual variability, than change in the ecological conditions. Continuation of monitoring campaigns will resolve this doubt. Timbebas reefs seem to be, among the coastal arc of reefs, those that exhibit the best conservation status regarding coral indices.

The occurrence of coral bleaching in the reefs of Bahia: The first register of coral bleaching in Bahia occurred in 1994, in the area of Abrolhos (Castro \& Pires 1999). In 1998 another sea surface temperature anomaly started in mid January (summer in the Southern hemisphere), attained its climax in mid March and beginning of April, and faded away by the end of May. During this event, two hot spots were registered, one in the North Coast of the State (Dutra 2000) and the other in Abrolhos (Leão et al. 2003). In both areas, the estimated sea surface temperature anomaly was about $1^{\circ} \mathrm{C}$, and matched with measurements of sea temperature in the field, which ranged between $29.5^{\circ} \mathrm{C}$ and $30.5^{\circ} \mathrm{C}$.

During our surveys from 2000 to 2005, coral bleaching registered attained more than $15 \%$ of the colonies in the reefs from Tinharé and Boipeba islands, and from the coastal arc of Abrolhos, in 2003, and in the Itacolomis reefs and, more extensively, in the fringing reefs of the Abrolhos Archipelago, in 2005 (Fig. 8).

Sea surface anomalies of $1{ }^{\circ} \mathrm{C}$ occurred in 2003 in the areas of Tinharé/Boipeba/Camamu and of Abrolhos (Fig. 9A, B). In Tinharé/ Boipeba/Camamu the sea surface temperature rose at the end of February, attained the maximum $\left(1{ }^{\circ} \mathrm{C}\right.$ anomaly) at the end of March and dissipated at the end of April (Fig. 9A). Coral bleaching was registered at the beginning of the month of May, when the percentages of colonies affected ranged from 12 to $23 \%$ (see Fig. 8). In Abrolhos sea surface temperature anomaly started in mid February, attained its climax during the whole month of March and dissipated at the end of April (Fig. 9B). Coral bleaching was observed in mid of March, when sea surface anomaly had just reached its maximum value $\left(1^{\circ} \mathrm{C}\right)$, but coral colonies were already affected, with up to $17.5 \%$ bleaching in the colonies (see Fig. 8).

During the hot spot event that occurred in Southern Bahia in 2005, two reef areas were affected, Itacolomis and Abrolhos, when bleached coral colonies attained values up to $28 \%$ in Abrolhos. A less extensive coral bleaching was observed in the Itacolomis Reefs where a maximum of $17 \%$ colonies per survey were found affected (see Fig. 8). The sea surface temperature started to rise in mid March, 
TABLE 12

Corals and millepores identified along band transects during recent surveys in the reefs of Bahia. 1.North Coast (Kikuchi 2000); 2. Todos os Santos Bay (Dutra et al. 2005); 3. Tinharé, Boipeba, Camamu; 4. Cabrália and Porto Seguro (Costa Jr 2001); 5. Itacolomis; 6. Abrolhos

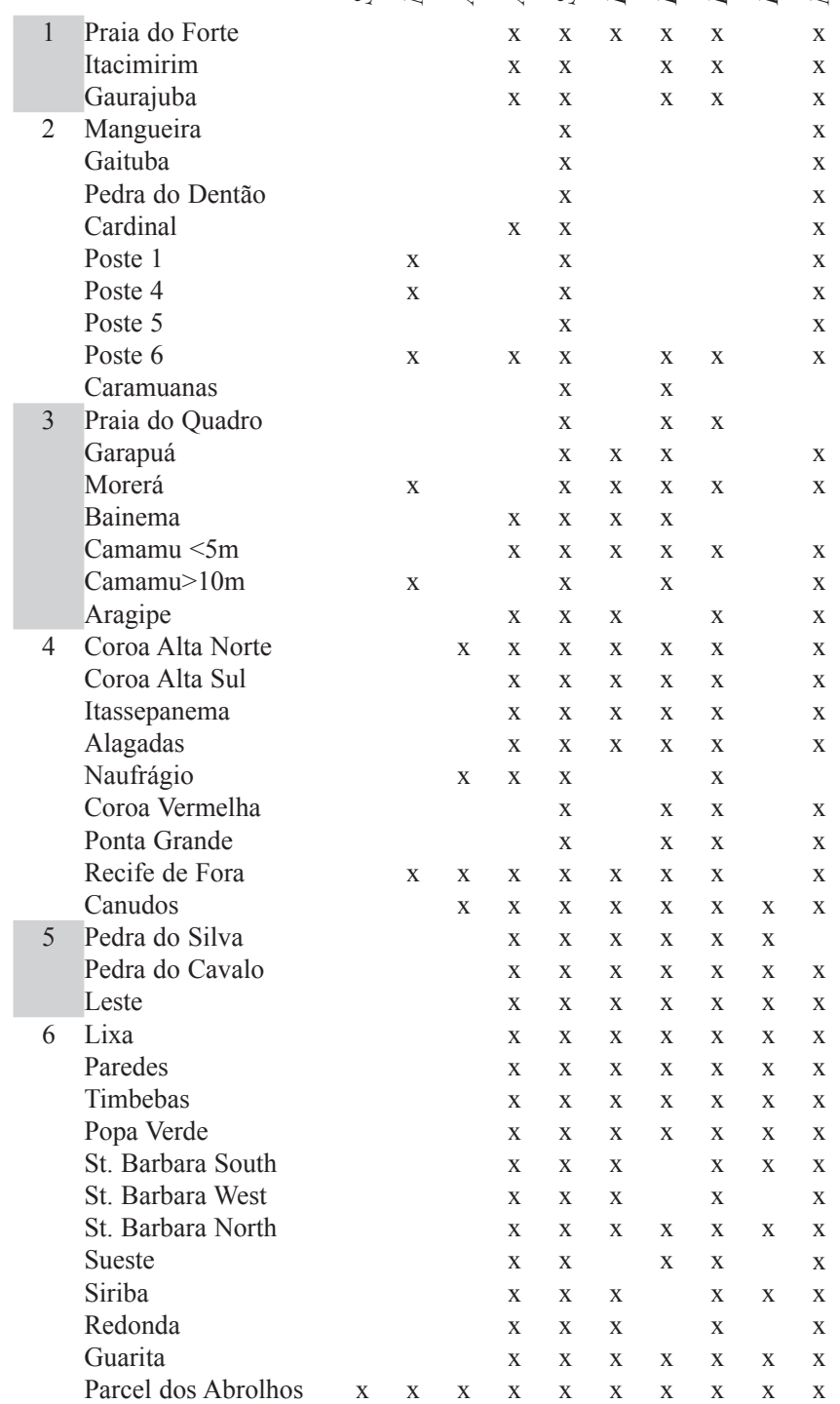
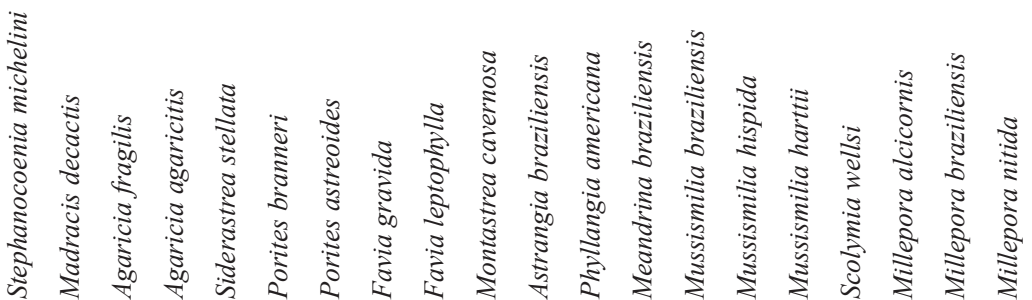

$$
\begin{array}{ccccc}
\mathrm{X} & \mathrm{X} & & & \mathrm{X} \\
\mathrm{X} & \mathrm{X} & \mathrm{X} & & \\
\mathrm{X} & \mathrm{X} & & & \mathrm{X} \\
& \mathrm{X} & & \mathrm{X} & \mathrm{X}
\end{array}
$$$$
x
$$$$
\begin{array}{lllllll} 
& x & x
\end{array}
$$$$
\mathrm{x}
$$$$
\mathrm{x} \quad \mathrm{x}
$$$$
\mathrm{x} x \mathrm{x}
$$$$
\mathrm{x} \quad \mathrm{x}
$$$$
\mathrm{x} \quad \mathrm{x}
$$$$
\begin{array}{llll}
\mathrm{x} & \mathrm{x} & \mathrm{x} & \mathrm{x}
\end{array}
$$$$
\begin{array}{llll}
\mathrm{X} & \mathrm{X} & \mathrm{x} & \mathrm{X}
\end{array}
$$$$
\begin{array}{lllll}
\mathrm{X} & \mathrm{X} & & & \\
\mathrm{X} & \mathrm{X} & \mathrm{x} & \mathrm{x} & \mathrm{X}
\end{array}
$$$$
\begin{array}{lll}
x & x & x
\end{array}
$$$$
\begin{array}{llll}
\mathrm{X} & \mathrm{X} & \mathrm{x} & \mathrm{X}
\end{array}
$$$$
\begin{array}{llll}
\mathrm{X} & \mathrm{x} & \mathrm{x} & \mathrm{X}
\end{array}
$$$$
\mathrm{x}-\mathrm{x}-2
$$$$
\begin{array}{llll}
\mathrm{x} & \mathrm{x} & \mathrm{x} & \mathrm{x}
\end{array}
$$$$
\begin{array}{lllll}
\mathrm{x} & \mathrm{x} & \mathrm{x} & \mathrm{x} & \mathrm{x} \\
\mathrm{x} & \mathrm{x} & \mathrm{x} & \mathrm{x} & \mathrm{x}
\end{array}
$$$$
\begin{array}{llll}
x & x & x
\end{array}
$$$$
\begin{array}{llllllll}
\mathrm{x} & \mathrm{X} & \mathrm{X} & \mathrm{x} & \mathrm{x} & \mathrm{x} & \mathrm{x}
\end{array}
$$$$
\begin{array}{lllll}
x & x & x & x & x
\end{array}
$$$$
\begin{array}{llll}
X & x & x & x
\end{array}
$$$$
\begin{array}{lllll}
x & x & x & x & x
\end{array}
$$$$
\begin{array}{llllllll}
\mathrm{X} & \mathrm{X} & \mathrm{X} & \mathrm{x} & \mathrm{x} & \mathrm{x}
\end{array}
$$$$
\begin{array}{lllllllll} 
& x & x & x & x & x & x & & x
\end{array}
$$

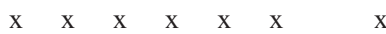$$
\begin{array}{lllll}
x & x & x & x
\end{array}
$$$$
\begin{array}{llllll}
x & x & x & x & x & x
\end{array}
$$$$
\begin{array}{lllll}
x & x & x & x
\end{array}
$$$$
\begin{array}{llll}
x & x & x & x
\end{array}
$$$$
\begin{array}{lllll}
x & x & x & x & x
\end{array}
$$$$
\begin{array}{llllll}
\mathrm{x} & \mathrm{X} & \mathrm{X} & \mathrm{x} & \mathrm{x}
\end{array}
$$$$
\begin{array}{llll}
\mathrm{X} & \mathrm{X} & \mathrm{X} & \mathrm{X}
\end{array}
$$$$
\begin{array}{lllll}
X & x & x & x
\end{array}
$$$$
\begin{array}{lllll}
x & x & x & x & x
\end{array}
$$

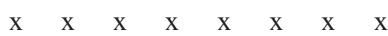




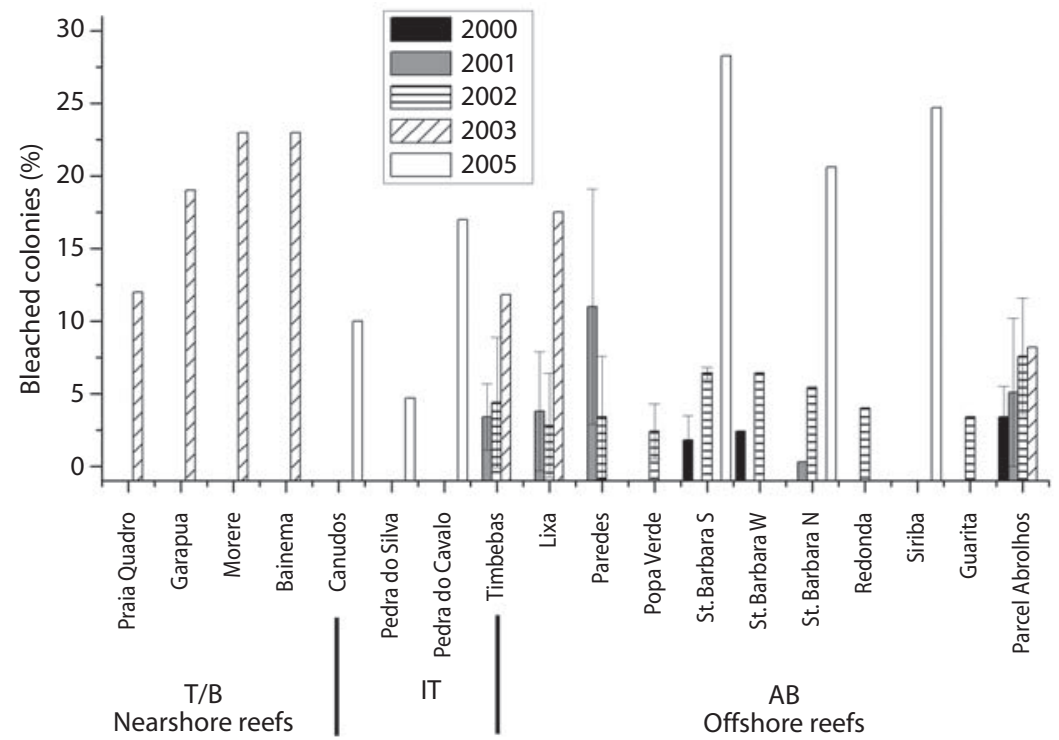

Fig. 8. Average percentages of bleached coral colonies measured during AGRRA surveys in the reefs along the coast of the State of Bahia, from 2000 to 2005. T/B= Tinharé and Boipeba islands. ITA=Itacolomis reefs. ABR=Abrolhos reef complex. Nearshore $=$ reefs located $\leq 5 \mathrm{~km}$ off the coast. Offshore $=$ reefs located $>5 \mathrm{~km}$ off the coast. Dashed bars illustrate bleaching during the 2003 El Niño event, and gray bars during the 2005 El Niño event.

attained the maximum value $\left(0.75^{\circ} \mathrm{C}\right)$ at the beginning of April, being completely dissipated at the end of this month (Fig. 9C).

An overall impression given by the occurrence of events of coral bleaching, in the surveyed reefs, is that there is a strong linkage between coral bleaching and periods of elevated sea surface temperatures, in the Bahia reefs.

The Southern reefs compared to the North Atlantic reefs: The set of coral vitality indices of the Southern reefs are distinct from those of the Northern reefs. Reefs in East cost of Brazil (SW Atlantic) have a lower live coral cover, lower bleached colonies in the years of survey and higher recent mortality compared to the NW Atlantic reefs. Despite the lower live coral cover, coral recruits density in offshore reefs of the SW Atlantic is much higher than the density found in the NW Atlantic reefs (Table 10). This contrast may be due to differences in species composition between the two regions, that results in a high frequency of species that do not grow significantly or that suffer frequent fragmentation in the Southern reefs, such as Siderastrea stellata, Porites branneri, Porites astreoides and Agaricia agaricites. Overall, SW Atlantic offshore reefs have better vital conditions than the nearshore reefs, and are less dissimilar to the NW Atlantic reefs than to the nearshore reefs. In terms of indicators, a lower live coral cover is compensated by the higher density of coral recruits in the offshore reefs. The higher recent mortality in SW Atlantic reefs have a multitude of causes. It has been shown that impacts of tourism, dredging operations, sewage and industrial pollution are important stressors of nearshore reefs (Coutinho et al. 1993, Costa Jr. et al. 2000, Leão and Kikuchi 2005, Dutra et al. 2006).

An overall scenario of the coral reefs of Bahia is that the nearshore reefs, which are located less than $5 \mathrm{~km}$ from the coast are in poorer condition (mean live stony coral cover $<4 \%$, mean density of coral recruits $<2$ 


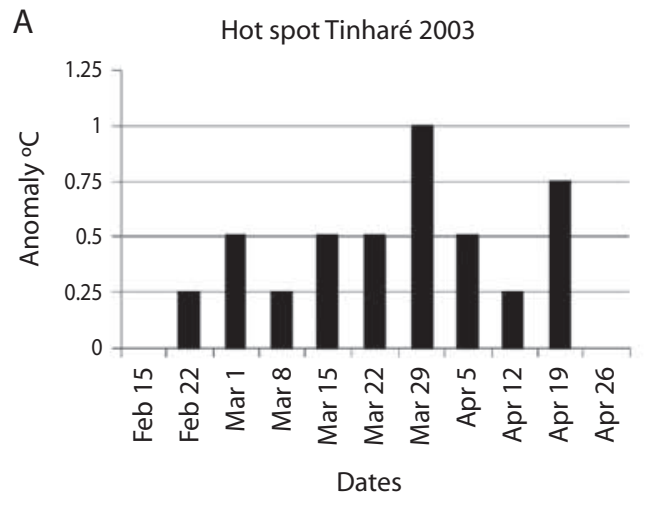

B
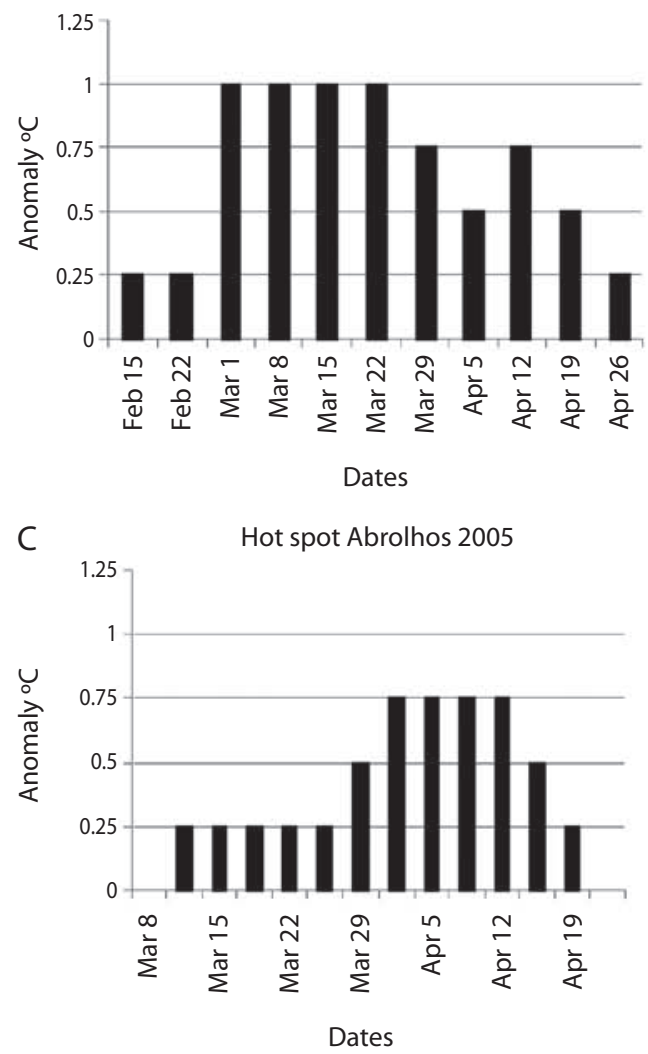

Fig. 9. Sea surface temperature anomalies along the coast of Eastern Brazil: Tinharé/Boipeba area for the year of 2003; Abrolhos area for the year of 2003, and Abrolhos area for the year of 2005. All based on hot spot charts available at http://www.osdpd.noaa.gov/PSB/EPS/SST/ climahot.html. recruits $/ \mathrm{m}^{2}$, mean density of corals larger than $20 \mathrm{~cm}<25$ individuals per reef site, the mean percentage of macroalgae $>40 \%$ ) than the reefs located more than $5 \mathrm{~km}$ off the coast (mean live stony coral cover $>11 \%$, mean density of coral recruits $>20$ recruits $/ \mathrm{m}^{2}$, mean density of corals larger than $20 \mathrm{~cm}>100$ corals per square meter and the mean percentage of macroalgae $<10 \%$ ).

It is already documented that the nearshore reefs of Bahia have been most severely impacted by anthropogenic effects such as euthrophic waters associated with sewage pollution, higher sedimentation rates and water turbidity, inadequate use of the reefs by tourists and over exploitation of their resources. And those conditions should represent the main causes that have been affecting the vitality of these nearshore reefs. An alert is raised here to the vital condition of some Abrolhos reefs situated in the coastal arc, which are very close to those of the nearshore group, since they have been already impacted and require management initiatives.

With a rise of sea level that will favor coastal erosion and increases reef eutrophification and sedimentation rates in the coastal areas, reef habitats in nearshore reefs must be fragmented, causing disruption in the interactions among species, producing major changes in the communities structure, biodiversity, and in the ecosystem functioning. The survival of the reefs exposed to those processes will depend upon an appropriate understand of all processes involved in the reef ecosystem functioning and maintenance, and on the effective management and sustainable use of their resources.

A more intensive investigation of the reefs that border the shores of the islands of the Abrolhos Archipelago, for comparison of the islands that are inaccessible to visitors with the recreational dive sites of St. Barbara Island is warranted, as well as the possible effects of winter storms damage to the reefs of the islands exposed to the Southern cold fronts that commonly occur during winter time. 
There is, thus, a need for creating a more effective monitoring program, in Bahia, with fixed reef sites in locations already known as having been impacted physically, biologically and chemically, as well as in areas where reefs are yet unaffected, in order to better identify indicators of the reef condition.

\section{ACKNOWLEDGMENTS}

The authors are especially grateful to all whom at least once were part of the AGRRA Team, from 2000 to 2005: Viviane Testa, Leo Dutra, Rodrigo Moura, Saulo Spanó, Claudio Sampaio, Bertrand Feitosa, Marcelo Telles, Rafael Silva, Igor Cruz, Eric Joelico and Antonio Bonicci-Neto. They also acknowledge the logistic support offered by the Parque Nacional Marinho dos Abrolhos (PARNAM Abrolhos) and the Conservation International- Brasil (CI Brasil) during field work. The AGRRA Organizing Committee provided financial support for the 2000 survey in Abrolhos. Part of the studies that produced the data used here received financial support from the Conselho Nacional do Desenvolvimento Científico e Tecnológico ( $\mathrm{CNPq})$, the Ministério de Ciência e Tecnologia do Brasil (MCT) and the Fundação de Apoio a Pesquisa do Estado da Bahia (FAPESB). The data from Tinharé, Boipeba and Camamu area were obtained for technical reports requested and funded by El Paso Óleo e Gás Ltda. Veracel Ltda. requested and funded the project for acquisition of data from Cabrália area. We are deeply indebted to Ian Macintyre and three other reviewers that have contributed with important criticisms to this article.

\section{RESUMEN}

Desde el año 2000 se inició un programa de monitoreo utilizando el protocolo AGRRA en el Parque Nacional Marino de Abrolhos en el marco de la creación del Nodo STA de la GCRMN. Entre 2000 y 2005 se realizaron varias evaluaciones en 26 arrecifes. Los patrones espaciales y temporales de la vitalidad de los arrecifes fueron estudiados mediante análisis de ordenación (MDS), similaridad (ANOSIM) y porcentajes de similaridad (SIMPER). La cobertura de coral vivo, la densidad de colonias grandes
$(>20 \mathrm{~cm})$ y de reclutas $(<2 \mathrm{~cm})$ y la cobertura de macroalgas indicaron que los arrecifes ubicados a más de $5 \mathrm{~km}$ de la costa presentan una mejor condición que aquellos ubicados a menos de $5 \mathrm{~km}$ de la costa. Los arrecifes más alejados registraron una mayor densidad de colonias, un bajo índice de macroalgas, un relativo más alto porcentaje de coberturas algales y una más alta densidad de reclutas en comparación con los arrecifes más cercanos. Los arrecifes más cercanos a la costa han sido más severamente afectados por las actividades humanas. Por ejemplo, eutrofización de aguas (contaminación de aguas residuales), mayor sedimentación y turbidez del agua, mal uso de los arrecifes y sobreexplotación de sus recursos. La implementación de un programa integral de monitoreo en Bahia es urgente y obligatorio para mejorar las estrategias de protección y los esfuerzos de manejo de sus arrecifes.

Palabras clave: Brasil oriental, arrecifes coralinos, protocolo AGRRA, monitoreo de arrecifes.

\section{REFERENCES}

Araújo, T.M.F. 1984. Morfologia, composição, sedimentologia e história evolutiva do recife de coral da Ilha de Itaparica, Bahia. M.Sc. Thesis, Instituto de Geociências, Universidade Federal da Bahia, Bahia, Brasil.

Aronson, R.B. \& D.W. Swanson. 1997. Video surveys: Uni and multivariate applications. Proc. 8th Int. Coral Reef Symposium 1: 1441-1446.

Belém, M.J.C., C. Rohlfs, D.O. Pires \& C.B. Castro. 1986. S.O.S. Corais. Revista Cienc. Hoje 5: 34-42.

Castro, C.B. 1994. Corals of Southern Bahia, p. 161-176. In: Hetzel \& C.B. Castro (eds.). Corals of Southern Bahia. B. Editora Nova Fronteira, Rio de Janeiro, Brasil.

Castro C.B. \& D.O. Pires. 1999. A bleaching event on a Brazilian coral reef. Rev. Bras. Oceanogr. 47: 87-90.

Clarke K.R. \& R.M. Warwick 1994. Change in marine communities: An approach to statistical analysis and interpretation. Plymouth, Natural Environmental Research Council, United Kindom.

Costa Jr, O.S. 1998. Efeitos da percolação da água do lençol freático nos recifes de coral das praias de Guarajuba e Papa Gente, litoral norte do Estado da Bahia. M.Sc. Thesis, Universidade Federal da Bahia, Instituto de Geociências, Bahia, Brasil.

Costa Jr, O.S. 2001. Nutrification and its effects on coral reefs from Southern Bahia, Brazil. Ph.D Thesis, University of Plymouth, Plymouth, United Kindom. 
Costa Jr, O.S., Z.M.A.N. Leão, M. Nimmo \& M. Atrill. 2000. Nutrification impacts on coral reefs from Northern Bahia, Brazil. Hydrobiologia 440: 307-316.

Coutinho, R. R.C. Villaça, C.A Magalhães, M.A Guimarães, M.A Apolinário \& G. Muricy. 1993. Influência antrópica nos ecosistemas coralinos da região de Abrolhos, Bahia, Brasil. Acta Biol. Leopoldensia 15: 133-144.

Dutra, L.X.C. 2003. Os efeitos do aporte de sedimento na vitalidade dos recifes de corais de Abrolhos, Bahia. M.Sc. Thesis. Universidade Federal da Bahia, Instituto de Geociências, Bahia, Brasil.

Dutra L.X.C. \& Kikuchi R.K.P. 2003. Método do vídeo transecto para diagnóstico de recifes de corais na Baía de Todos os Santos, Bahia. Proc.VI Congresso de Ecologia do Brasil 1: 341-343.

Dutra, L.X.C., R.K.P. Kikuchi \& Z.M.A.N. Leão. 2006. Effects of sediment accumulation on reef corals from Abrolhos, Bahia, Brazil. J. Coastal. Research SI 39: 633-638.

Figueiredo, M.A.O. 1997. Colonization and growth of crustose coralline algae in Abrolhos, Brazil. Proc. 8th Int. Coral Reef Symposium 1: 689-694.

Francini-Filho, R.B., R.L. Moura, F.L. Thompson, R.M. Reis, L. Kaufman, R.K.P.

Gasparini, J.L., S.R. Floeter, C.E.L. Ferreira \& I. Sazima 2005. Marine ornamental trade in Brazil. Biodivers. Conserv. 14: 2883-2899.

Ginsburg, R.N., P.A. Kramer, J.C. Lang \& P. Sale. 1998 Atlantic and Gulf Rapid Reef Assessment (AGRRA) revised rapid assessment protocol (RAP) (http:// agrra.org).

Hawkins, J. P., C. M. Roberts 1997. Estimating the carrying capacity of coral reefs for SCUBA diving. Proc. 8th Int. Coral Reef Symposium 2: 1923-1926.

Kikuchi, R.K.P. \& Z.M.A.N. Leão. 1998. The effects of Holocene sea level fluctuations on reef development and coral community structure, North Bahia, Brazil. Ann. Acad. Bras. Ciênc. 70: 159-171.

Kikuchi, R.K.P. 2000. Modificações na comunidade dos corais construtores dos recifes da costa norte da Bahia durante a regressão holocênica. Ph.D. Thesis, Instituto de Geociências, Universidade Federal da Bahia, Salvador, Bahia, Brasil.

Kikuchi, R.K.P., Z.M.A.N. Leão, V. Testa, L.X.C. Dutra \& S. Spanó. 2003a. Rapid assessment of the Abrolhos
Reefs, Eastern Brazil (Part 1: Stony corals and algae). Atoll Res. Bull. 496: 172-187.

Kikuchi, R.K.P., Z.M.A.N. Leão, C.L.S. Sampaio, M.D. Telles. 2003b. Rapid assessment of the Abrolhos Reefs, Eastern Brazil (Part 2: Fish communities). Atoll Res. Bull. 496: 189-204.

Kikuchi \& Z.M.A.N. Leão 2008. Disease leading to accelerated decline of reef corals in the largest South Atlantic reef complex (Abrolhos Bank, eastern Brazil). Mar. Pol. Bull. 56: 1008-1014.

Krammer, P.A. 2003. Synthesis of coral reef health indicators for the Western Atlantic: results of the AGRRA program (1997-2000). Atoll Res. Bull. 496: 1-58.

Laborel, J.L. 1969. Les peuplements des madreporaires des côtes tropicales du Brésil. Annales Univ. d'Abidjan, Serie E, II, Fasc. 3: 39-47.

Laborel, J.L. 1970. Madreporaires et hydrocoralliaires récifaux des côtes bresiliennes. Systematique, écologie, repartition verticale et géographie. Ann. del'Institut Oceanogra. de Paris 47: 171-229.

Leão, Z.M.A.N. 1982. Morphology, geology and developmental history of the Southernmost coral reefs of Western Atlantic, Abrolhos Bank, Brazil. Ph.D. Thesis, RSMAS, University of Miami, Florida, USA.

Leão, Z.M.A.N. 1983. Abrolhos: O refúgio pleistocênico de uma fauna terciária de corais. Ver. Ciênc. Terra 8: $22-24$.

Leão, Z.M.A.N \& R.N. Ginsburg. 1997. Living reefs surrounded by siliciclastic sediments: the Abrolhos coastal reefs, Bahia, Brazil. Proc. 8th Int. Coral Reef Symposium 2: 1767-1772.

Leão, Z.M.A.N., R.K.P. Kikuchi, M.P. Maia \& R.A.L. Lago. 1997. A catastrophic coral cover decline since 3000 years BP, Northern Bahia, Brazil. Proc. 8th Int. Coral Reef Symposium 1: 583-588.

Leão Z.M.A.N., R.K.P. Kikuchi, V. Testa, M.D. Telles, J.L.J. Pereira, L.X.C. Dutra \& C.L.S. Sampaio. 1999. First coral reef assessment in the Southern hemisphere applying the AGRRA rapid protocol (Caramuanas Reef, Bahia, Brazil). Int. Conf. Sci. Aspects Coral Reef Assess. Monitor. Restor. (Fort Lauderdale, Florida): $422-423$

Leão, Z.M.A.N \& J.M.L. Dominguez 2000. Tropical coast of Brazil. Mar. Pol. Bull. 41: 112-122.

Leão, Z.M.A.N., R.K.P. Kikuchi \& V. Testa. 2003. Corals and coral reefs of Brazil, p. 9-52. In J. Cortés (ed.). 
Latin American Coral Reefs. Elsevier Science B.V., Amsterdam, The Netherlands.

Leão Z.M.A.N. \& R.K.P. Kikuchi. 2005. A relic coral fauna threatened by global changes and human activities, Eastern Brazil. Mar. Pol. Bull. 51: 599-611.

Leão Z.M.A.N., R.K.P. Kikuchi, L.X.C. Dutra \& M.D.M. Oliveira. 2006. The status of Eastern Brazil coral reefs during the last 5000 years. Proc. 10th Int. Coral Reef Symposium 1: 959-968.

Lessa, G.C., A.C.S.P. Bittencourt, A. Brichta \& J.M.L. Dominguez. 2000. A reevaluation of the late Quaternary sedimentation in Todos os Santos Bay (BA) Brazil. An. Acad. Bras. Ciênc. 72:573-590.

Meesters, E.H., I. Wesseling \& R.P.M. Bak. 1996. Partial mortality in three species of reef-building coral and the relation with colony morphology. Bull. Mar. Sci. 58: 838-852.

Neves, E. 2004. Complexo Siderastrea: Espécies distintas? Significado da variabilidade do gênero Siderastrea de Blainville, 1830 (Anthozoa, Scleractinia) no Brasil. Ph.D. Thesis, Instituto de Biociências, Universidade de São Paulo, São Paulo, Brasil.

Nolasco, M.C. \& Z.M.AN. Leão. 1986. The carbonate buildups along the Northern coast of the State of Bahia, Brazil, 4: 159-190. In J. Rabassa (ed.). Quaternary of South America and Antarctic Peninsula, Balkema Pub. Company, Rotterdam, The Netherlands.

Nolasco, M.C. 1987. Construções carbonáticas da costa norte do Estado da Bahia (Salvador a Subauna). M.Sc. Thesis, Universidade Federal da Bahia, Salvador, Bahia, Brasil.

Page C., G. Coleman, R. Ninio \& K. Osborne. 2001. Surveys of benthic reef communities using underwater video. Australian Institute of Marine Sciences, Townsville, Australia.

Pitombo, F., C.C. Ratto \& M.J.C. Belém. 1988. Species diversity and zonation pattern of hermatypic corals at two fringing reefs of Abrolhos Archipelago. Brazil. Proc. 6th Int. Coral Reef Symposium 2: 817-820.

Reis, M.A.C. 2001. A ação bioerosiva da esponja Cliona celata (Grant 1826) (Porifera - Desmopongia) no coral Siderastrea stellata Verrill 1868, dos recifes do litoral norte do estado da Bahia. Ph.D. Thesis, Universidade Federal as Bahia, Instituto de Geociências, Bahia, Brasil.

Reis, M.A.C. \& Z.M.A.N. Leão. 2003. Bioerosion rate of the sponge Cliona celata (Grant 1826) from reefs in turbid waters, North Bahia, Brazil. Proc. 8th Int. Coral Reef Symposium 1: 273-278.

Santa-Izabel, L.M., Z.M.A.N. Leão, \& M.C. Peso-Aguiar. 2000. Polychaetes from the Guarajuba coral reefs, Bahia, Brazil. Bull. Mar. Sci. 67: 645-653.

Santa-Izabel, L.M. 2001. Caracterização da bioerosão interna dos recifes de Guarajuba com ênfase nos macroperfuradores bivalvos, sipunculídeos e poliquetas, litoral norte do estado da Bahia. Ph.D. Thesis, Univeridade Federal da Bahia, Instituto de Geociências, Bahia, Brasil.

Silveira, I.C.A., L.B. Miranda \& W.S. Brown. 1994. On the origins of the North Brazil Current. J. Geophys. Res. 99: 22501-22512.

Spanó, S., Z.M.A.N. Leão \& R.K.P. Kikuchi. 2008. Diagnóstico do estado de conservação dos recifes em franja do Parque Nacional Marinho dos Abrolhos. OLAM: Ciência e Tecnologia 8: 245-277.

Stramma, L. 1991. Geostrophic transport of the South Equatorial Current in the Atlantic. Mar. Res. 49:281294.

U.S. Navy. 1978. Marine climatic atlas of the World, vol. IV, South Atlantic Ocean, Washington D.C., USA.

Villaça, R. \& F.B. Pitombo. 1997. Benthic communities of shallow-water reefs of Abrolhos, Brazil. Rev. Bras. Oceanogr. 45: 35-43. 
